\title{
24. SEISMIC REFRACTION MEASUREMENTS IN THE CENTRAL INDIAN BASIN: EVIDENCE FOR CRUSTAL THICKENING RELATED TO INTRAPLATE DEFORMATION ${ }^{1}$
}

\author{
Gregory T. Leger,,$^{2,3}$ Keith E. Louden ${ }^{2}$
}

\begin{abstract}
Three, $100-\mathrm{km}$-long seismic refraction profiles were taken in the Central Indian Basin within a region affected by intraplate compression. Parallel lines were placed on top of a symmetrically upwarped and faulted basement ridge and along the adjacent trough. These were partially joined by a perpendicular line spanning the two regions. Two ocean-bottom seismometers and three disposable sonobuoys per line received shots from a large air-gun array. Six individual seismic record sections, which displayed well-defined and laterally continuous $P$-wave and $S$-wave phases, were selected from these data and divided into two groups for detailed analysis.

Results from waveform modeling show a standard oceanic crustal structure for the trough, consisting of a 2.6to $2.7-\mathrm{km}$-thick layer $2\left(V_{p}\right.$ ranging from 4.6 to $6.6 \mathrm{~km} / \mathrm{s}$ and $V_{s}$ from 2.6 to $\left.3.5 \mathrm{~km} / \mathrm{s}\right)$ underlain by a $2.3-\mathrm{km}$-thick layer $3 \mathrm{a}\left(V_{p}=6.7 \mathrm{~km} / \mathrm{s}\right.$, and $\left.V_{s}=3.9 \mathrm{~km} / \mathrm{s}\right)$ and a $2.0-\mathrm{km}$-thick layer $3 \mathrm{~b}\left(V_{p}=7.4 \mathrm{~km} / \mathrm{s}\right.$, and $\left.V_{s}=4.3 \mathrm{~km} / \mathrm{s}\right)$, for a total crustal thickness of $6.9-7.0 \mathrm{~km}$. The structure under the ridge has similar velocities but a total thickness of $8.6-8.9 \mathrm{~km}$. This increase is created entirely by the thickening of layers $3 \mathrm{a}$ (by $26 \%$ ) and $3 \mathrm{~b}$ (by $40 \%-46 \%$ ), as constrained by observations of $P$ - and $S$-wave wide-angle reflections from the top and bottom of layers $3 \mathrm{a}$ and $3 \mathrm{~b}$. Sediment densities constrained by measurements from Ocean Driilling Program (ODP) Sites 717 and 718 , together with a range of possible crustal densities suggested by the seismic velocities, show that crustal thickening of this nature is consistent with the observed gravity anomaly.

Such crustal thickening is inconsistent with models of lithospheric deformation caused by the buckling of a strong but thin elastic core. Rather, it conforms more closely to models of hydrodynamic viscous flow that allow for folding accompanied by periodic layer thickening within a lithosphere of only moderate yield strength. These models are consistent with the wavelength and height of the observed deformation as well as the existence of deep focus earthquakes. Further observations are required, however, before we can be certain whether this thickening was created by intraplate deformation or was produced at the time of crustal magma generation and only influenced the location of deformation.
\end{abstract}

\section{INTRODUCTION}

The Central Indian Basin, south of Sri Lanka between the Ninetyeast and Chagos-Laccadive ridges, is a region far from plate boundaries that displays clear evidence of intraplate lithospheric deformation. This deformation is best observed in geoid images and the geoid-derived free-air gravity field. These anomalies show lineations that trend east-west with amplitudes up to $2 \mathrm{~m}$ and $70 \mathrm{mGal}$, respectively, and wavelengths of 100 to $300 \mathrm{~km}$ (Weissel et al., 1980; Stein et al., 1989). Although there is no obvious cause for such features in the seafloor bathymetry, seismic reflection profiles show that the basement undulates in a similarly lineated pattern. Basement highs and lows correlate with the geoid anomalies but are mostly hidden beneath a thick sediment drape from the Bengal Fan (Eittreim and Ewing, 1972; Weissel et al., 1980; Geller et al., 1983). The magnitude and wavelength of the gravity anomaly appears to indicate a lack of isostatic equilibrium beneath the ridges, such as would be produced by lithospheric buckling under horizontal compression (Weissel et al., 1980; McAdoo and Sandwell, 1985).

Additional reflection profiles recently reported by Neprochnov et al. (1988) have characterized these large-scale

\footnotetext{
${ }^{1}$ Cochran, J. R., Stow, D.A.V., et al., 1990. Proc. ODP, Sci. Results, 116: College Station, TX (Ocean Drilling Program).

2 Department of Oceanography, Dalhousie University, Halifax, N.S., Canada, B3H $3 \mathrm{~J} 5$.

${ }^{3}$ Oceanroutes Canada, 271 Brownlow Ave., Dartmouth, N.S., Canada, B3B 1W6.
}

deformation features, not as long uninterrupted ridges but rather as sets of individual tectonized blocks, bounded by pre-existing fracture zones to the east and west and by more recent high-angle faults to the north and south. Smaller scale features with wavelengths of 5 to $20 \mathrm{~km}$ also exist (Eittreim and Ewing, 1972; Weissel et al., 1980; Geller et al., 1983), and these appear to be faulted and rotated thrust blocks that have been recently active (Cochran and Stow et al., 1989). Such faults could allow fluid movement from below to create zones of high heat flow, such as observed at Ocean Drilling Program (ODP) Site 717 (Shipboard Scientific Party, 1989a), as well as the nonlinear gradients that have been previously observed throughout the same general region (Geller et al., 1983).

Widespread active faulting is consistent with the existence of a diffuse region of teleseismic and microseismic activity throughout the region (Sykes, 1970; Wiens et al., 1985; Neprochnov et al., 1988). It is thought that these earthquakes are caused by movement along small, pre-existing faults under general regional compression. Consistent teleseismic focal mechanisms indicate that compressive stress is maximal in a north-south direction (Wiens and Stein, 1983; Bergman and Solomon, 1985). Numerical modeling of the stress field in the Indo-Australian Plate shows that a superposition of forces focus and magnify compression into a similar north-south orientation within the region of the intraplate deformation (Cloetingh and Wortel, 1986). The magnitude of the predicted compressive stress is not as consistently determined as its orientation but has been estimated between $400 \mathrm{MPa}(4 \mathrm{kbar})$ (Cloetingh and Wortel, 1986) and several tens of MPa (Richardson, 1987). 
Not even the greater of these estimates is, however, large enough to cause the buckling of a purely elastic plate with a thickness of 40 to $50 \mathrm{~km}$, considered by studies of oceanic flexure (Bodine et al., 1981) as appropriate for this region's Late Cretaceous to early Paleocene age (Sclater and Fisher, 1974). Indeed, simple elastic beam theory requires a horizontal stress close to $5 \mathrm{GPa}$ ( $50 \mathrm{kbar}$ ) for such buckling, which is higher than the failure strength of typical lithospheric rocks (Kirby, 1983). McAdoo and Sandwell (1985) alleviated this problem by considering an elastic-plastic model with a brittleductile rheological structure, as determined by experimental rock mechanics for an olivine-dominated lithosphere (Goetze and Evans, 1979). This rheology produces a temperature- and pressure-dependent strength envelope, which is a function of both depth and lithospheric age. Conditions for buckling were found by considering the bending moment integral as a function equivalent to an effective elastic flexural rigidity, in which the maximum yield stress is a function of depth. This result predicts buckling, with wavelengths closely resembling those observed in the geoid data, at a greatly reduced stress level $(600 \mathrm{MPa})$ roughly consistent with the higher values predicted for the stress field (Cloetingh and Wortel, 1986).

This model predicts an effective elastic core thickness of approximately $12 \mathrm{~km}$ centered at a depth of $20 \mathrm{~km}$. However, the existence of earthquake hypocenters at depths ranging from 10 to $40 \mathrm{~km}$ (Wiens and Stein, 1983; Bergman and Solomon, 1980, 1985) suggests that nonelastic deformation is occurring over a more extensive depth interval. In addition, the buckling model contains a thin-plate approximation that does not consider shear stresses due to vertical loading, and results only in asymmetric deformation. This led Zuber (1987) to formulate an alternative theory, which considers the hydrodynamic flow of one or two viscous layers with different strengths overlying a viscous substrate in which strength decreases exponentially with depth. Lithospheric deformation occurs as a result of the amplification of small random disturbances at the interfaces between layers with different mechanical properties. This method predicts a range of deformational styles with buckling and inverse boudinage (pinch and swell) as the end members. Deformation falling between these two extremes, in which folding is accompanied by periodic layer thickening, best conformed to observations of deformational wavelength $(180 \mathrm{~km})$, strong layer thickness ( 30 $\mathrm{km})$ and average compressive stress (200-600 MPa).

A major difference between styles of deformation predicted by elastic-plastic buckling vs. viscous hydrodynamic flow is that for buckling. The thickness of the crust (as well as that of the lithosphere) should stay constant; whereas for hydrodynamic flow, upper layers with intermediate strength will be dynamically thickened under topographic highs by approximately $30 \%$. Although a preliminary analysis of the gravity field suggested that local isostatic thickening did not occur (Weissel and Haxby, 1982), it is difficult to distinguish between models with no thickening and models with dynamic (i.e., non-isostatic) thickening, without further constraints on the density and thickness of sediment and crustal layers.

To help characterize the style of deformation and to constrain the analysis of the geoid and gravity anomalies, we wanted to determine thickness and velocity variations in sediment and crustal layers across a typical ridge-trough compressional feature. Toward this objective, we conducted a series of crustal refraction and sediment reflection profiles. The results presented in this paper suggest that the oceanic crust is thicker beneath the anticlinal ridge associated with the gravity high than beneath the adjacent trough. All of this thickening occurs within oceanic layer 3. Simple gravity calculations, with layer densities constrained by seismic velocities within the crust and sediment, agree well with the observed geoid-derived free-air gravity field. These new results favor the viscous hydrodynamic flow model for deformation of a lithosphere with intermediate thickness and strength. Further observations are required, however, before we can be certain whether this thickening was created by intraplate deformation or was produced at the time of crustal magma generation and only influenced the location of deformation.

\section{EXPERIMENTAL DESIGN}

Figure 1 shows the region of the Central Indian Basin affected by intraplate deformation, including the generalized location of the lineated free-air gravity highs (Stein et al., 1989), basement ridges and troughs (Geller et al., 1983; Neprochnov et al., 1988), and magnetic anomalies and their associated fracture zones (Sclater and Fisher, 1974; Shipboard Scientific Party, 1989b). The area of our particular refraction experiment was located approximately $450 \mathrm{~km}$ south of the drilling sites of ODP Leg 116, at the very distal end of the Bengal Fan sediments (Cochran, Stow et al., 1989). Two north-south reflection profiles (Eittreim and Ewing, 1972; Geller et al., 1983), which previously crossed this region along $80^{\circ} \mathrm{E}$, had clearly delineated a symmetrically upwarped and faulted basement ridge (at $4^{\circ} 15^{\prime} \mathrm{S}$ ) bounded by two troughs (at $3^{\circ} 30^{\prime} \mathrm{S}$ and $5^{\circ} 20^{\prime} \mathrm{S}$ ). This ridgetrough system has a relatively uniform sediment cover (Neprochnov et al., 1988) and is coincident with the lineated gravity anomalies (Fig. 1).

To measure differences in crustal velocity structure between a basement high and low, three $100-\mathrm{km}$-long seismic refraction profiles were situated along and to the south of this basement feature (Fig. 2). We tried as far as possible to avoid complicating structures that might be associated with the Afanasiy Nikitin Seamounts to the east and the fracture zone to the west (Fig. 1). Refraction lines 1 and 3 were run in an east-west orientation, parallel to the deformation, to minimize variations in crustal velocity structure, water depth and sediment thickness. Line 2 was a dip line to provide correlation between lines 1 and 3 .

The lines were shot with a 6050 in. $^{3}(99.2$ l) air-gun array, consisting of eight guns with sizes varying between 540 in. $^{3}$ $(9.8 \mathrm{l})$ and $1000 \mathrm{in.}^{3}$ (16.4 1), at an average shot pressure of 1800 psi $(12.4 \mathrm{~Pa})$ and shot spacing of $180 \mathrm{~m}$. A single-channel hydrophone streamer was used to collect simultaneous, digitally recorded vertical incidence reflection data. Wide-angle seismic data were collected using disposable sonobuoys (S/B) and ocean-bottom seismometers (OBS). Sonobuoy hydrophone data were digitally recorded with an 8-ms sampling interval from two locations on profile 1 and three locations on each of profiles 2 and 3. Two, four-channel analog oceanbottom seismometers, including hydrophone, vertical and single horizontal geophones (Heffler and Barrett, 1979), were used on each line. Ship positions were determined by combining GPS and transit satellite navigation. Final OBS positions on the seafloor were corrected by minimizing traveltime residuals between calculated and observed water-wave firstarrivals from nearby shots.

\section{REFLECTION PROFILES}

The normal-incidence reflection data along the three refraction profiles are shown in Figures 3-5. Profile 1 (Fig. 3) was recorded from west to east along a basement trough (geoid minimum). The western third of the line was not recorded digitally due to a computer failure (dashed part of line in Fig. 2) and therefore could not be replayed. However, original paper records indicate that this section has the same character as the remainder of the profile. Profile 3 (Fig. 5) was shot from west to east along a bathymetric and basement high (geoid maximum), $150 \mathrm{~km}$ to the north of profile 1 . Profile 2 (Fig. 4) 


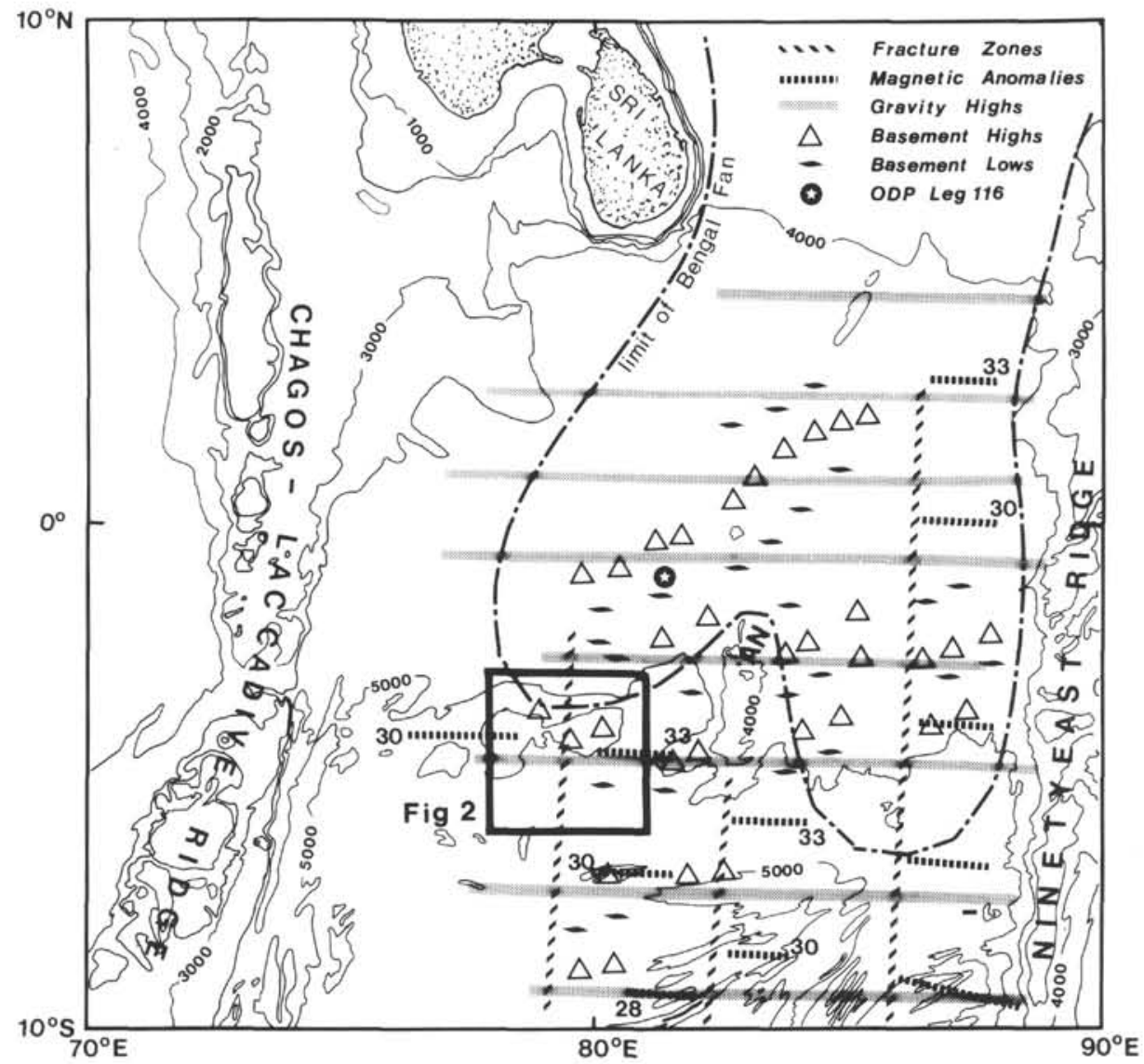

Figure 1. Regional tectonic map of the Central Indian Basin showing location of study area and ODP Leg 116 sites. Bathymetry in selected $1000-\mathrm{m}$ contours from GEBCO chart (Canadian Hydrograhic Office, 1982); magnetic anomalies and fracture zones from Sclater and Fisher (1974) and Shipboard Scientific Party (1989b); basement highs and lows are those common both to Geller et al. (1983) and Neprochnov et al. (1988); generalized location of lineated free-air gravity highs from Stein et al. (1989); and approximate limit of Bengal Fan from Cochran, Stow et al. (1989). AN = Afanasiy-Nikitin Seamount

is a dip line from north to south over the southern half of the deformational feature. It intersects profile 3 at the joint position of OBS $2 \mathrm{C} / 3 \mathrm{C}$.

Profile 2 (Fig. 4) shows basement faults that have clearly disturbed the overlying sediments during the growth of the deformational ridge. There is only a very thin $(0.05-$ to $0.09-\mathrm{s})$ post-deformational sediment layer that lies unconformably above reflector $B$. Offsets in two-way traveltime between major reflectors in the sediment column are identical to offsets in the basement. This might suggest that faulting occurred completely after deposition of the primary turbidite sequence. However, we will show in the following section that moveouts of wide-angle reflections, both from internal sediment layers and from the sediment-basement interface, require increases in sediment velocity with depth. Values in the upper layers $(1.6-2.0 \mathrm{~km} / \mathrm{s})$ are similar to those observed at ODP Sites $717-719$, but are roughly $30 \%$ less than the velocity of $2.6 \mathrm{~km} / \mathrm{s}$ near the basement. This means that the true offset of the basement thrust faults must also be $30 \%$ greater than their surface expression.

This discrepancy can be accommodated by having two primary sedimentary sequences below the post-deformation unconformity: a lower sequence deposited before deformation began (pre-deformation) that has a relatively constant thickness between ridge and trough; and an upper sequence deposited during deformation (syn-deformation) that has a variable thickness. Approximately one-third of basement offsets took place during deposition of the syn-deformational sequence, before the long-wavelength deformation may have reached sufficient amplitude to shut off the supply of turbidites.

This same situation is clearly demonstrated by reflection profiles at ODP Sites 717-719 (Shipboard Scientific Party, 1989 b), which show a highly reflective syn-deformational layer of variable thickness overlying a more transparent pre-deformational layer of constant thickness. Following this similarity, we identify reflector $A$ in profiles $1-3$ as the seismo-stratigraphic boundary between the syn-deformation and pre-deformation sediments. The identification of this reflector, however, is not as clear as at the ODP sites, probably because the large air-gun array, configured for the refraction experiment, creates a low-frequency record dominated by multiples from the banded turbidite sequences. These appear as later arrivals within the pre-deformation unit. For instance, the deeper reflector $\mathrm{X}$ on top of the ridge, at approximately $7 \mathrm{~s}$ on profiles 2 and 3 , is possibly a multiple created by an internal reflection between boundaries $\mathrm{A}$ and $\mathrm{B}$.

Our identification of reflectors A and B suggests the following:

1. The largest post-deformational sediment thickness above reflector B $(0.09 \mathrm{~s})$ on our profiles is less than half of the typical values $(0.2 \mathrm{~s})$ that are observed at the ODP Leg 116 


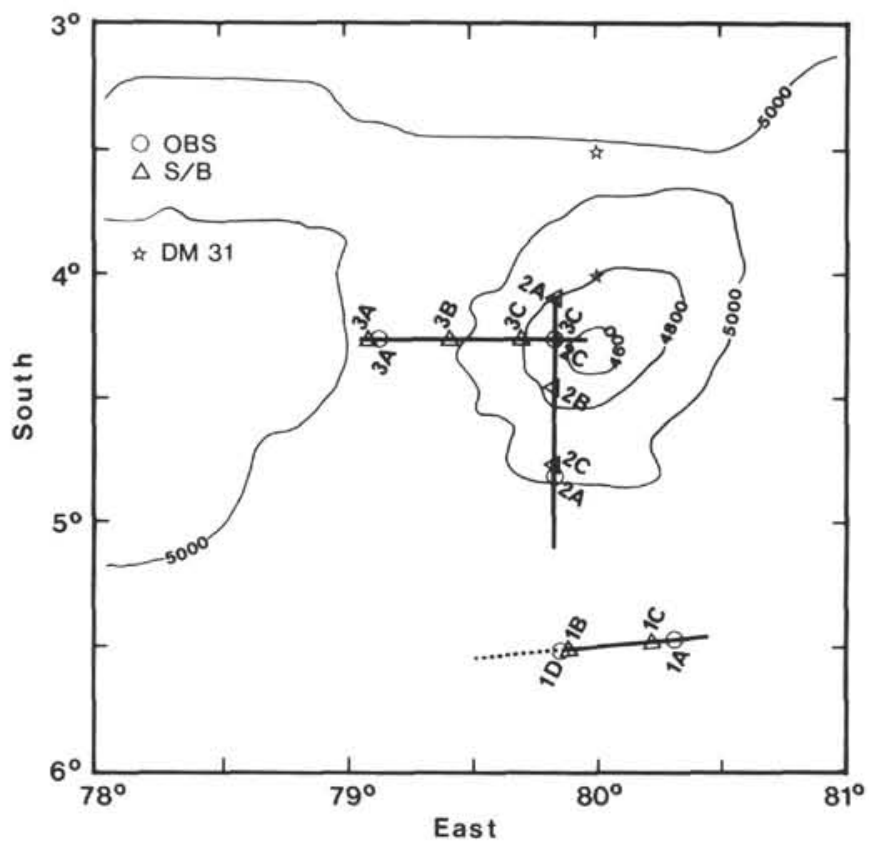

Figure 2. Detailed location map of reflection profiles 1-3 shown in Figures 3-5. Position of OBS and S/B instruments for seismic refraction record sections shown in Figures 8 to 10 and A1 to A4. Broken line indicates section of profile 1 that was not digitally recorded. Positions of DM31 OBS observations from Neprochnov et al. (1988). Bathymetric contours (in meters) from ETOPO5 digital data base.

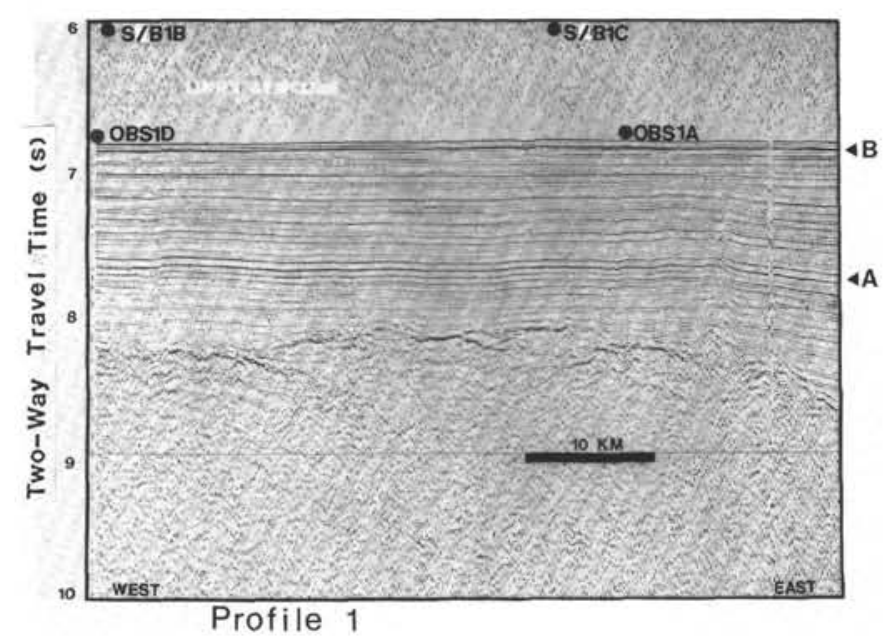

Figure 3. Reflection profile 1 along strike of a basement trough (see Fig. 2 for location). Location of refraction instruments and prominent sediment reflectors (A and B) as identified. Notice broken nature of basement reflector.

drill sites, $450 \mathrm{~km}$ to the north. This thinning is probably caused by a reduction in sediment transport at the distal end of the Bengal Fan. A limitation of sediment supply also may have occurred as a result of the creation of topographic barriers during the latest stages of the deformation (Scott and Leger, this volume).

2. The thickness of the syn-deformational sequence between reflectors $\mathrm{A}$ and $\mathrm{B}$ changes from relatively constant values of $0.8 \mathrm{~s}$ on profile 1 (Fig. 3) to $0.4 \mathrm{~s}$ on profile 3 (Fig. 5). Changes in thickness occur abruptly in localized zones of intense faulting on profile 2 , such as at the faults marked by arrows in Fig. 4. Similar changes in thickness from 0.15 to 0.6 $\mathrm{s}$ over distances of $10 \mathrm{~km}$ have been documented at the Leg 116 sites (Shipboard Scientific Party, 1989b).

3. The pre-deformation sediment thickness below reflector $\mathrm{A}$ is relatively constant at $0.6-0.7 \mathrm{~s}$ on profiles 1,2 , and the eastern half of profile 3 . It is much less than thicknesses of 1.15 to $1.35 \mathrm{~s}$ that are observed at the Leg 116 sites and suggests that the fan was building to the south during this period.

There are some additional basement features on the reflection profiles that pre-date the intraplate deformation. On profile 3 (Fig. 5), there is a disturbed basement reflector beginning under $\mathrm{S} / \mathrm{B} 3 \mathrm{~B}$ and extending approximately $20 \mathrm{~km}$ to the west. This feature only influences the reflectors in the sediments immediately overlying, and not the subsequent fan deposits. This implies that it was not created by the deformational event and is more likely associated with processes of seafloor spreading. We interpret it as the basement expression of the Indrani fracture zone, which has been previously located nearby from offsets in magnetic anomalies (Fig. 1). To the west of this fracture zone, the basement rises and progressively terminates the lower sediment layers. This also indicates a pre-deformational origin. Finally, we note that the character of the basement reflector on profile 1 (Fig. 3) appears to be dominated by weak diffraction hyperbolas, suggesting that it is produced by a rough surface. This differs from the stronger, more continuous basement reflections in profiles 2 and 3 . The origins of this irregular basement relief are unclear, except that they pre-date the overlying sediments that are undisturbed by the relief. This irregularity may have affected $P$-wave to $S$-wave conversions, explaining why shear-wave phases are much weaker on this line.

\section{REFRACTION PROFILES}

We have separated our refraction profiles into two groups, for subsequent analysis of first-order variations in crustal structure between the ridge and trough. One group, representing the structure of the faulted basement ridge, includes instruments $\mathrm{S} / \mathrm{B} 2 \mathrm{~A}, \mathrm{~S} / \mathrm{B} 3 \mathrm{C}$, and $\mathrm{OBS} 3 \mathrm{C}$; the other, representing the undeformed trough, includes instruments $S / B$ B, S/B 2C, and OBS 1A. Each group represents data where bathymetric relief is minimal and sediment thickness is nearly constant. Other data not used in this analysis were either: disrupted by the fracture-zone structure on profile 3 (S/B 3A, OBS $3 \mathrm{~A}$, and S/B 3B); had insufficient shot-receiver offsets (S/B 1C); or were of poor data quality (OBS 1D). Instruments OBS $2 \mathrm{C}$, OBS $2 \mathrm{~A}$, and S/B $2 \mathrm{~B}$ document transitions between the ridge and trough structures but were not included in this initial analysis using only homogeneous models.

\section{Record Sections}

Sonobuoy data were provided in digital format by LamontDoherty Geological Observatory. Analog OBS data were digitized at Atlantic Geoscience Centre (Bedford Institute of Oceanography), with an average sampling interval of $88 \mathrm{~Hz}$ per channel, later interpolated to $60 \mathrm{~Hz}$ and linearly corrected for clock drift rate (typically $<2 \mathrm{~ms} / \mathrm{hr}$ ).

Record sections are presented for all profiles in Figures 9, 10 , and A1 to A4 at reducing velocities of $8 \mathrm{~km} / \mathrm{s}$ (for $P$-wave analysis) and $4 \mathrm{~km} / \mathrm{s}$ (for $S$-wave analysis). Traveltime variations due to changes in water depth were corrected using the method of Purdy (1982). No corrections were made for the sediment that has a relatively constant thickness over the length of each individual profile. To enhance both the nearvertical and wide-angle characteristics of the arrivals on the same plot, the data are presented in a half-wave, variable-area 


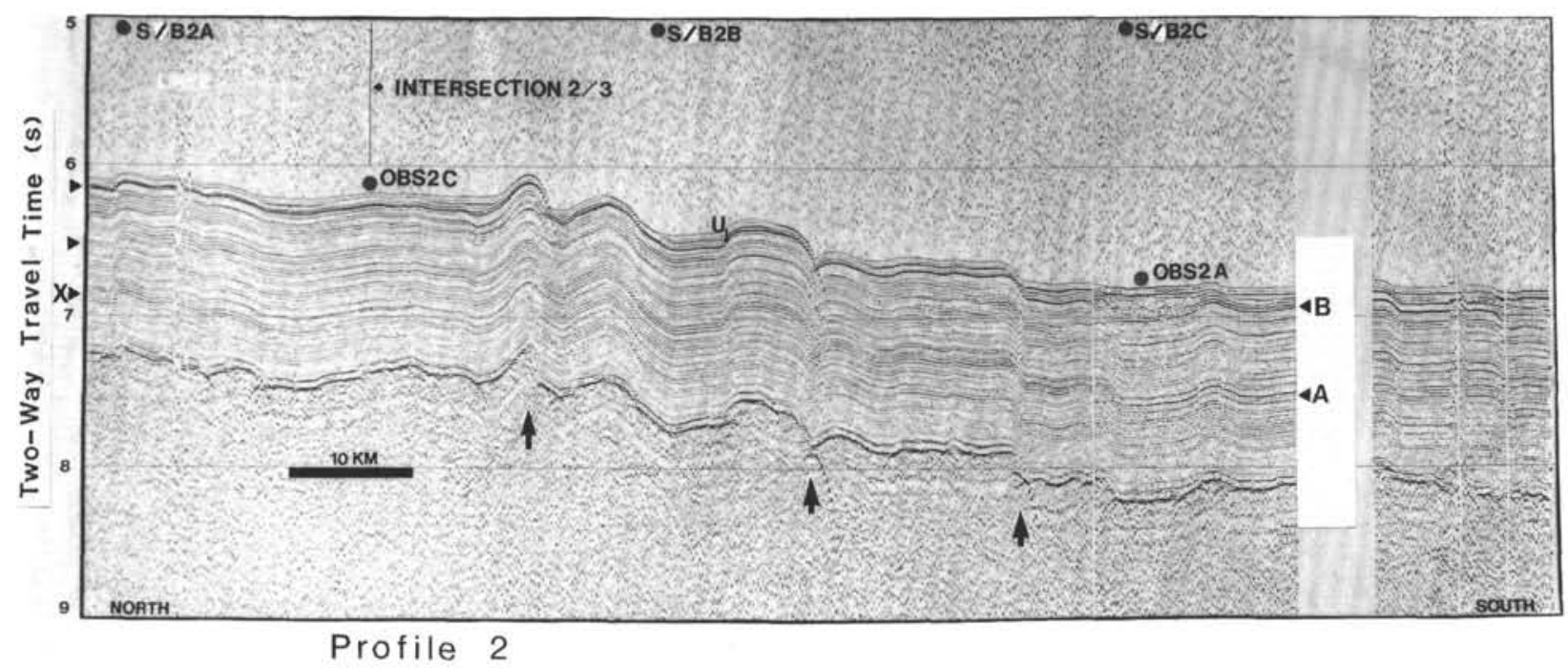

Figure 4. Reflection profile 2 (location shown in Fig. 2), which runs from north to south across basement ridge and trough. Location of refraction instruments, prominent sediment reflectors (A, B, and X) and intersection with profile 3 as identified. Arrows indicate the position of basement faults with major offsets, across which syn-deformation sediments thin toward the ridge.

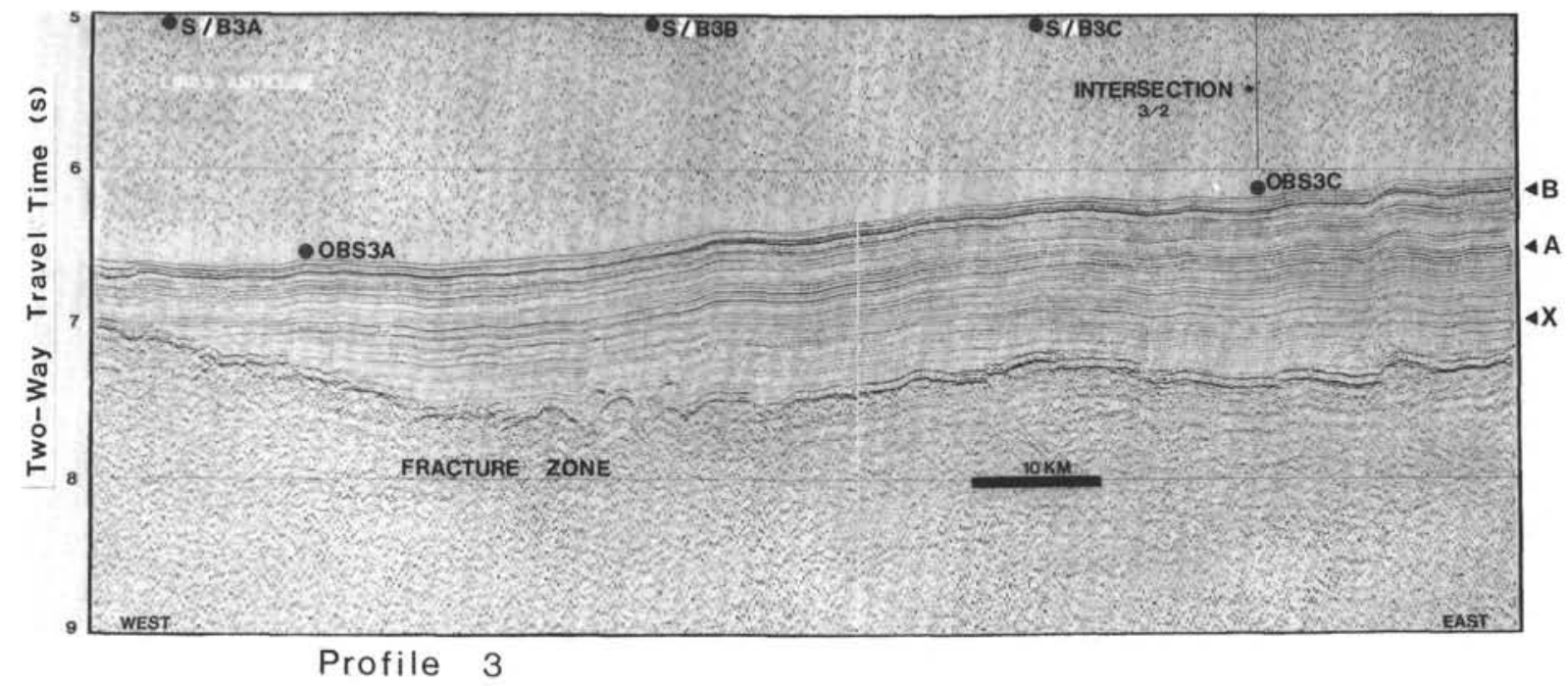

Figure 5. Reflection profile 3 (location in Fig. 2), which runs along the basement and gravity highs and crosses the Indrani fracture zone (location shown in Fig. 1) at the position of the disturbed basement reflector. Location of refraction instruments, prominent sediment reflectors $(\mathrm{A}, \mathrm{B}$, and $\mathrm{X})$ and intersection with profile 2 as identified. Notice the progressive termination of the lower sediment layer as basement rises to the west of the fracture zone.

format with positive peaks omitted and negative peaks clipped at a pre-set maximum. Amplitude is increased with range $(R$ in $\mathrm{km})$ by a factor $F$ where $F=F_{\mathrm{o}}(1+R / 8)$. All records sections are bandpass-filtered from 3.5 to $15 \mathrm{~Hz}$. Tracing mixing was not used to increase signal-to-noise ratios from the weak but repetitive air-gun source, to preserve the full variety of phase velocities and amplitudes.

Geophone data from the OBS are not presented (see Leger, 1989 for the complete data) as they are generally of poorer data quality and are dominated by shear-wave reverberations within the sediment layers directly below the receivers, as previously described by Lewis and McClain (1977). Note that the OBS hydrophone channels are affected by cross-talk from the clock channel, which did not affect the geophone channels. In addition, on OBS $1 \mathrm{~A}$ the $12-\mathrm{kHz}$ acoustic pinger, which is used as a deployment and recovery aid, did not switch off. Both types of noise appear on the records with infinite phase velocity and, therefore, do not greatly interfere with our analysis of real arrivals with phase velocities of 8 $\mathrm{km} / \mathrm{s}$ or less.

\section{Plane-layer Solutions From First-arrival Times}

For each record section (Figs. 9, 10, A1 to A4), we first performed simple $\mathrm{T}^{2}-\mathrm{X}^{2}$ analysis on wide-angle reflections from sediment layers, identified from the normal incidence records, and T-X analysis on crustal refractors, identified as first-arrivals along linear segments. These yield six $P$-wave plane-layer velocity structures (Fig. 6), which we compare with the previous two structures determined in a similar manner by Neprochnov et al. (1988). The results are remarkably consistent within the ridge and trough groups, given the rather large uncertainty in identifying separate layers. They show the following general features: 


\section{PLANE- LAYER VELOCITY STRUCTURE}

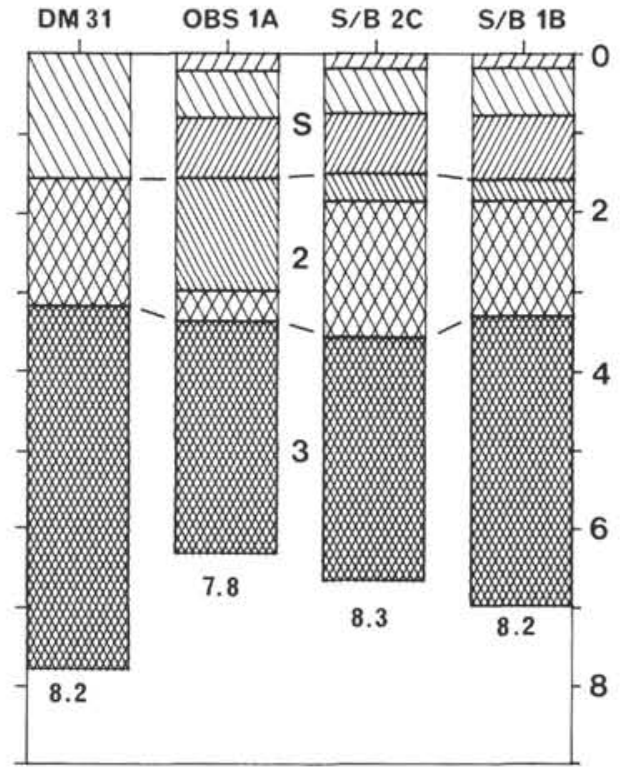

TROUGH

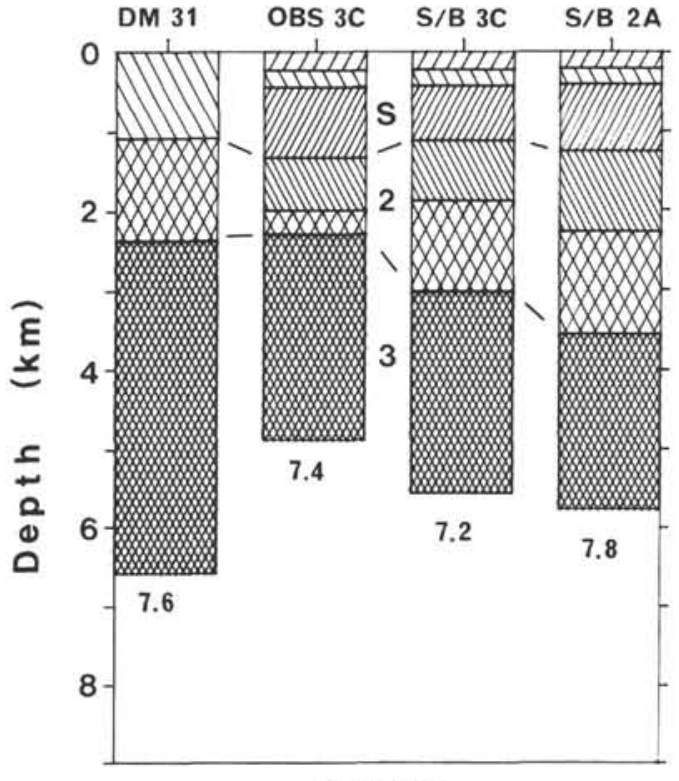

RIDGE

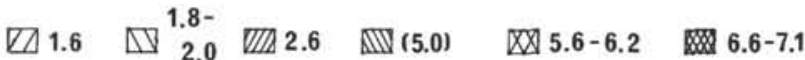

Figure 6. Homogeneous plane-layer seismic velocity-depth solutions for RC2706 OBS and S/B refraction profiles (this study) and DM31 OBS profiles (Neprochnov et al., 1988). Velocities are given in km/s for the sediment (S), layer 2, layer 3, and presumed mantle. Profiles are grouped to represent trough and ridge structures.

1. The sediment velocities increase with depth from 1.6 $\mathrm{km} / \mathrm{s}$ at the seafloor to $2.6 \mathrm{~km} / \mathrm{s}$ above basement. Average sediment thickness increases from $1.2 \mathrm{~km}$ on the ridge to 1.6 $\mathrm{km}$ in the trough. This thickness variation is conservative and somewhat underestimated compared to that of Neprochnov et al. (1988), because we have used a higher average velocity structure for the ridge sediment structure (i.e., the $2.6-\mathrm{km} / \mathrm{s}$ transition occurs higher in the column). Velocity data from Sites 717-719 (Cochran and Stow et al., 1989) show that velocity increases with depth do not conform to the seismic boundaries, apart from the upper unconformity at reflector B. Thus, it is probable that the transition to the $2.6-\mathrm{km} / \mathrm{s}$ velocity is depth dependent, rather than strictly occurring at reflector $\mathrm{A}$, and occurs further down the column for the ridge structure.

2. Layer 2 has observed velocities of 5.9 and $6.2 \mathrm{~km} / \mathrm{s}$ that underlie an assumed lower velocity lid. This agrees with basement velocities of 5.7 and $6.3 \mathrm{~km} / \mathrm{s}$, reported by Eittreim and Ewing (1972) from two sonobuoys at approximately $7^{\circ} \mathrm{S}$, $80^{\circ} 45^{\prime} \mathrm{E}$, and with values of 5.6 and $6.1 \mathrm{~km} / \mathrm{s}$ reported by Neprochnov et al. (1988). These high, layer 2b and 2c type, velocities are expected from old crust covered by a thick sediment layer. The thickness of layer 2 is quite variable, between 0.97 and $2.3 \mathrm{~km}$ for the ridge and 1.71 and $2.05 \mathrm{~km}$ for the trough. This variability, both within and between groups, is probably caused by the well-known uncertainty in measuring layer 2 structure from first-arrivals alone. There is no indication that layer 2 changes between ridge and trough structures.

3. Layer 3 velocities, between 6.8 and $7.1 \mathrm{~km} / \mathrm{s}$ for the trough and 6.6 and $6.7 \mathrm{~km} / \mathrm{s}$ for the ridge, are quite characteristic of oceanic crust. Average thicknesses vary between 3.2 $\mathrm{km}$ for the trough and $2.4 \mathrm{~km}$ for the ridge. Our respective velocities are close to the 6.6 and $6.9 \mathrm{~km} / \mathrm{s}$ values of Neprochnov et al. (1988), but our thicknesses are less than their values of 4.6 and $4.2 \mathrm{~km}$, which correspond more closely to standard oceanic crust.

4. Sub-layer 3 velocities are distinctly different between ridge and trough profiles; values of 7.8 to $8.3 \mathrm{~km} / \mathrm{s}$ under the trough are much more characteristic of the upper mantle than the lower and more variable velocities of 7.2 to $7.8 \mathrm{~km} / \mathrm{s}$ under the ridge. It seems likely that the distant arrivals from the ridge profiles are not a low-velocity upper mantle, as suggested by Neprochnov et al. (1988), but rather are either misidentified wide-angle reflections or refractions from a lower crust, high-velocity layer.

\section{Structure from Synthetic Seismograms}

In our use of synthetic seismograms to refine the firstarrival velocity structures of Fig. 6, we were more interested in a gross, first-order comparison of the average crustal structure between ridge and trough than in the fine details of specific layers at particular receivers. Thus, we found it convenient to use the simpler, if somewhat less exact, asymptotic ray method of Cerveny and Ravindra (1971). In addition, we could perform these calculations rapidly using a microcomputer, even at the same high-density spatial sampling intervals found on the observed record sections. For these computations, we used a source signature represented by a simple damped sinusoid (Cerveny et al., 1977), with frequencies of $6 \mathrm{~Hz}$ for the OBS and $10 \mathrm{~Hz}$ for the sonobuoys, a time window of $5 \mathrm{~s}$ (corresponding to the observed record sections), and time interval of $10 \mathrm{~ms}$ (intermediate between the 
OBS and S/B sampling intervals of $16.7 \mathrm{~ms}$ and $8 \mathrm{~ms}$, respectively).

Synthetics for the first-arrival structures are given in Fig. 7. A comparison to S/B 2A for the ridge structure (Fig. 9) and S/B 1B for the trough structure (Fig. 10) shows that they are not very close approximations to the observed record sections for the following reasons:

1. The predicted high-amplitude reflections off the top and bottom of layer 3 are not observed near normal incidence.

2. Strong first-arrivals from layer 2 and $3\left(P_{2}, P_{3}\right)$ between 10 and $20-25 \mathrm{~km}$ in the observed records are not present in the synthetics.

3. Arrival times for the wide-angle reflections $(\mathrm{PmP})$ off the top of the 7.5 -to $8.2-\mathrm{km} / \mathrm{s}$ layer arrive too early, particularly for the ridge profile.

4. High-amplitude second arrivals that are observed between 18 and $27 \mathrm{~km}$ for the ridge profiles do not match the synthetics.

5 . The linear pattern of strong second arrivals between 18 and $30 \mathrm{~km}$ on the observed trough record section, with apparent velocities between layer 3 and mantle, are not

\section{Synthetics for Plane-Layer Structures}
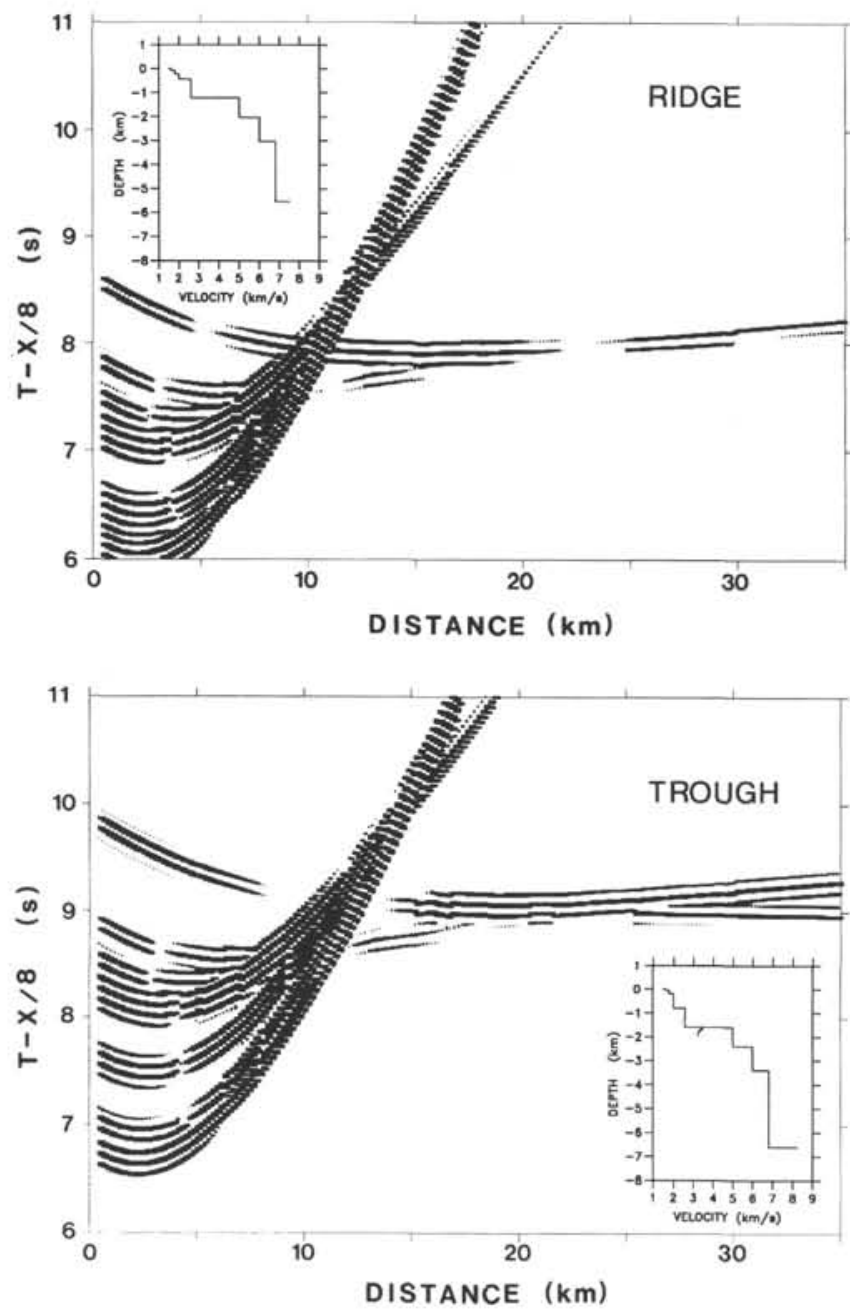

Figure 7. Asymptotic ray synthetic seismograms for average ridge and trough velocity-depth structures given by the plane-layer solutions of Figure 6. observed in the synthetics and suggest the need for an additional layer with intermediate velocity.

6. A more complex and thicker lower crustal section is also suggested by the width of the second-arrival wavetrain at distances beyond $20 \mathrm{~km}$ in both structures but particularly noticeable on the ridge.

7. Cross-over to mantle refractions at $25 \mathrm{~km}$ as well as high amplitudes beyond $30 \mathrm{~km}$ for the trough synthetics are not observed.

Similar discrepancies are present between the synthetics of Figure 7 and the other records sections presented in the Appendix (Figs. A1 to A4).

To improve the fit between the observed and synthetic seismograms, we perturbed the velocity-depth structure from the first-arrival solutions of Figure 6 to our final model (Table 1 and Fig. 11). The following major changes were required:

1. The velocity structure in the sediment below the initial $1.6-\mathrm{km} / \mathrm{s}$ layer varies predominantly with depth and is not fixed to the seismic horizons of the normal incidence reflection profiles.

2. Discrete layers $2 b$ and $2 c$ were replaced by multiple layers to mimic a strong velocity gradient of $1.4 / \mathrm{s}$ (from velocities of 4.6 to $5.8 \mathrm{~km} / \mathrm{s}$ within the upper $1 \mathrm{~km}$ ) and a weak gradient of $0.23 / \mathrm{s}$ (from velocities of 6.0 to $6.6 \mathrm{~km} / \mathrm{s}$ ) in the lower $1.5 \mathrm{~km}$.

3. Layer 3 was divided into two layers, $3 a$ and $3 b$, with respective velocities of 6.7 and $7.4 \mathrm{~km} / \mathrm{s}$. Both of these layers are required to be approximately $30 \%-40 \%$ thicker for the ridge structure than for the trough.

Complete comparisons between synthetic seismograms from our revised ridge and trough velocity-depth structures and the six observed record sections are given in Figures 9, 10 , and A1 to A4. A detail of wide-angle reflections and initial basement refractions is given in Figure 8 for $\mathrm{S} / \mathrm{B} 3 \mathrm{C}$ on the ridge (see Fig. 2 for locations). Although some discrepancies

Table 1. Velocity distribution for synthetic seismograms.

\begin{tabular}{|c|c|c|c|c|c|c|}
\hline Layer & $\begin{array}{c}V_{p} \\
(\mathrm{~km} / \mathrm{s})\end{array}$ & $\begin{array}{c}\mathrm{H}_{\mathrm{R}} \\
(\mathrm{km})\end{array}$ & $\begin{array}{l}\mathrm{H}_{\mathrm{T}} \\
(\mathrm{km})\end{array}$ & $\begin{array}{c}V_{s} \\
\left(\mathrm{~km}^{\prime} / \mathrm{s}\right)\end{array}$ & $\begin{array}{c}\mathrm{H}_{\mathrm{R}} \\
(\mathrm{km})\end{array}$ & $\begin{array}{c}\mathrm{H}_{\mathrm{T}} \\
(\mathrm{km})\end{array}$ \\
\hline Sediment & $\begin{array}{l}1.6 \\
1.7 \\
1.8 \\
2.0 \\
2.6\end{array}$ & $\begin{array}{l}0.10 \\
0.12 \\
0.11 \\
0.32 \\
0.51 \\
1.16\end{array}$ & $\begin{array}{l}0.17 \\
0.12 \\
0.11 \\
0.32 \\
0.65 \\
1.37\end{array}$ & & & \\
\hline Layer 2 & $\begin{array}{l}4.6 \\
5.3 \\
5.6 \\
5.8 \\
6.0 \\
6.3 \\
6.4 \\
6.5 \\
6.6\end{array}$ & $\begin{array}{l}0.40 \\
0.20 \\
0.10 \\
0.19 \\
0.19 \\
0.44 \\
0.65 \\
0.22 \\
0.22\end{array}$ & $\begin{array}{l}0.40 \\
0.20 \\
0.10 \\
0.19 \\
0.19 \\
0.44 \\
0.65 \\
0.22 \\
0.22\end{array}$ & 3.3 & $\begin{array}{l}0.4 \\
0.8\end{array}$ & 0.4 \\
\hline $\mathrm{H}_{2}$ & & 2.61 & 2.61 & & 2.7 & 2.7 \\
\hline $\begin{array}{c}\text { Layer } 3 \\
\mathrm{H}_{3}\end{array}$ & $\begin{array}{l}6.7 \\
7.4\end{array}$ & $\begin{array}{l}3.00 \\
3.00 \\
6.00\end{array}$ & $\begin{array}{l}2.30 \\
2.00 \\
4.30\end{array}$ & $\begin{array}{l}3.9 \\
4.3\end{array}$ & $\begin{array}{l}3.0 \\
3.2 \\
6.2\end{array}$ & $\begin{array}{l}2.3 \\
2.0 \\
4.3 \\
\end{array}$ \\
\hline $\begin{array}{r}\text { Mantle } \\
\mathrm{H}_{\mathrm{CR}}\end{array}$ & 8.1 & 8.42 & 6.72 & 4.7 & 8.9 & 7.0 \\
\hline
\end{tabular}

Average interval layer thicknesses (in $\mathrm{km}$ ) for ridge profiles $\left(\mathrm{H}_{\mathrm{R}}\right)$ and trough profiles $\left(\mathrm{H}_{\mathrm{T}}\right)$ used in calculations of synthetic seismograms in Figures 8-10 and A1-A4.

Total thicknesses (in $\mathrm{km}$ ) given for sediment $\left(\mathrm{H}_{\mathrm{S}}\right)$, layer $2\left(\mathrm{H}_{2}\right)$, layer $3\left(\mathrm{H}_{3}\right)$ and crust $\left(\mathrm{H}_{\mathrm{CR}}\right)$ 
remain, the revised synthetics give a much improved fit to the observations. In particular we note that:

1. The sediment model with higher velocity at depth gives a good general fit to the flattening with depth of the wide-angle moveouts from the sediment layers, as observed in Figure 8. Specific correlation between wide-angle and normal incidence reflectors is made difficult by the ringing nature of the reflectors and the low-frequency response and repetition rate of the large air-gun array.

2 . The upper crustal $P$-wave velocity structure $\left(P_{2}\right)$ is well constrained because our plotting algorithm allows us to trace individual phases through the seafloor water-wave reflection (Fig. 8). More limited resolution exists for $S$-wave phases $\left(S_{2}\right)$ because of additional interference due to refraction breakouts from the sediment layers. A large jump in velocity at the sediment-basement interface is suggested by high-amplitude, wide-angle reflections (B in Fig. 8; also see discussion of $S$-waves below). Inclusion of a velocity gradient in the upper crust has reproduced the amplitude patterns in the first-arrival phases, $P_{2}$ and $P_{3 a}$, and the lack of sub-critical reflections from layers 2 and $3 \mathrm{a}$ between $6-7$ and $25 \mathrm{~km}$. The rapid decrease in the amplitudes of the $P_{3 \mathrm{~b}}$ first-arrival phase beyond this range and the strength of the sub-critical reflection phase, $P_{3 \mathrm{~b}} P$, are modeled by a sharp boundary and decreasing velocity gradient within layer $3 \mathrm{~b}$.

3. The addition of layer $3 \mathrm{~b}$ in both ridge and trough structures has improved their arrival times and amplitudes in the range between 18 and $30 \mathrm{~km}$. Increasing the thickness of layers $3 \mathrm{a}$ and $3 \mathrm{~b}$ in the ridge structure produces a wider wavetrain (by superposition of additional phases) at $25-30 \mathrm{~km}$ as compared to the trough profiles. Compare $P$-wave arrivals for S/B 2A (Fig. 9a) vs. S/B 1B (Fig. 10a), S/B 3C (Fig. Ala) vs. S/B 2C (Fig. A2a), and OBS $3 \mathrm{C}$ (Fig. A3a) vs. OBS $1 B$ (Fig. A4a). For the trough profiles, the relative thinness of these layers reproduces the linear pattern of second arrivals with intermediate phase velocities observed between 18 and
$30 \mathrm{~km}$. Note in particular the good fit to the $P$-wave interference effects for S/B 1B (Figs. 10a and 10b).

Important evidence for the existence of thicker layers $3 \mathrm{a}$ and $3 \mathrm{~b}$ beneath the ridge profiles comes from an analysis of $S$-waves. Our ridge profiles are marked by the presence of strong $P$ to $S$ conversions at the sediment-basement interface. This occurs primarily because $V_{s}$ in the upper basement is approximately equal to $V_{p}$ in the lower sediment and because $V_{p}$ is high and Poisson's ratio is low $\sigma=0.265$ from measured $V_{s}$ and $V_{p}$ in Table 1) in the upper basement (White and Stephen, 1980; Spudich and Orcutt, 1980). Because of their slow velocities, $S$-waves often suffer interference from latearriving $P$-wave multiples. This makes their identification and analysis difficult. At the same time, however, the slower $S$-wave velocity almost doubles the two-way traveltime between reflectors, resulting in a greater separation and visibility between phases such as $S_{\mathrm{m}} S$ and $S_{3 \mathrm{~b}} S$ as compared with $P_{\mathrm{m}} P$ and $P_{3 \mathrm{~b}} P$. Observation of these $S$-wave phases from the ridge profiles of S/B 2A (Fig. 9c), S/B 2C (Fig. A2c), and OBS 3C (Fig. A3c) at ranges of $20-35 \mathrm{~km}$ form our best constraints on the thicknesses of layers $3 \mathrm{a}$ and $3 \mathrm{~b}$ on the ridge.

Unfortunately, these phases are not as clear on the trough profiles, possibly because basement faulting, which has created the rather rough and hyperbolic appearance of the basement reflector on the normal incidence reflection profile (Fig. 3), also has decreased the $S$-wave velocity and increased Poisson's ratio in the uppermost basement. As might be expected, this effect is variable along profile; $S$-wave arrivals from S/B 1B (Fig. 10c) are weakest and those from OBS 1A (Fig. A4c) are strongest. For S/B 2C (Fig. A2C) they are difficult to estimate because the recording failure between ranges of 15 and $21 \mathrm{~km}$ makes positive identification of the later arrivals difficult.

Not all of the characteristic patterns in the synthetics as discussed above are present on each of the individual record sections. This indicates the presence of some inhomogeneities. For instance, the persistent $P_{3 \mathrm{~b}} P$ high-amplitude, wide-

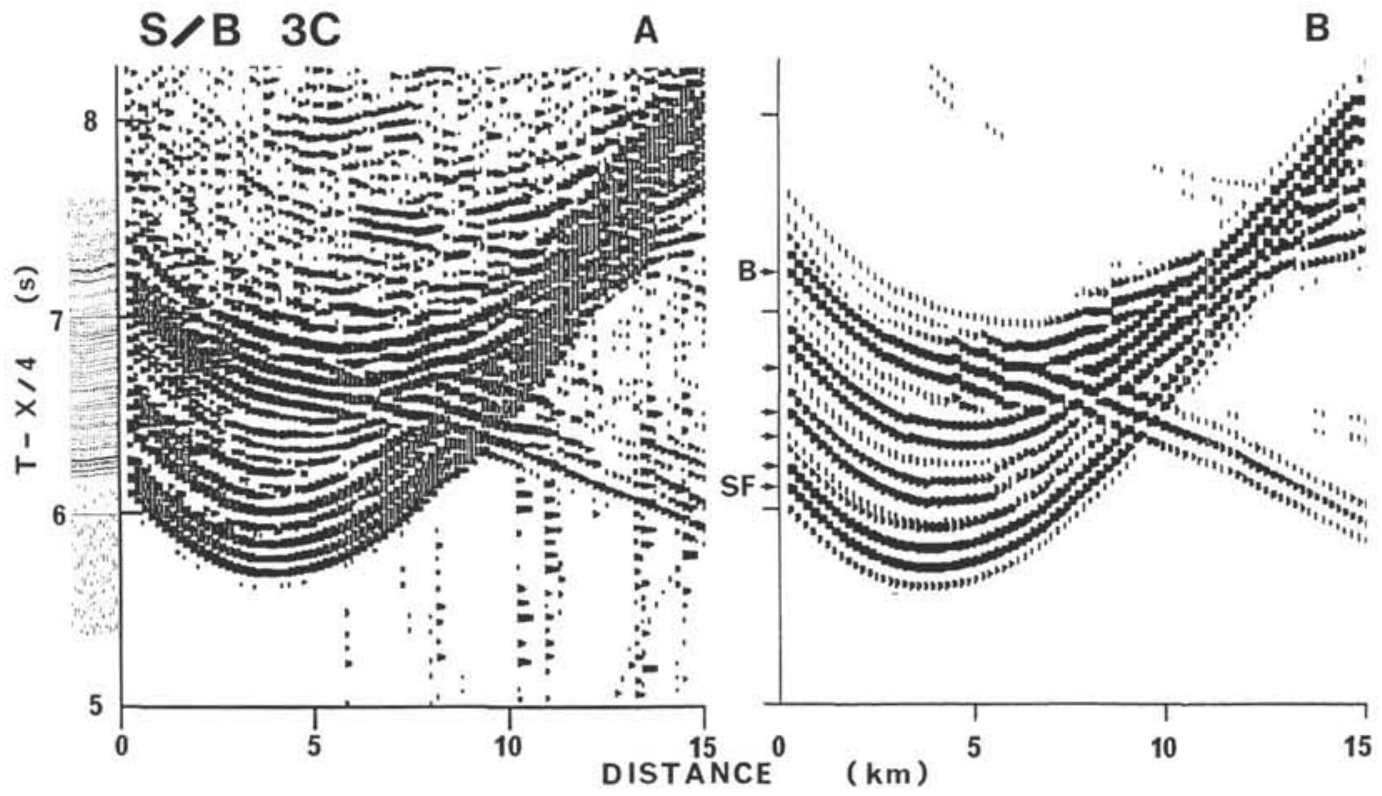

Figure 8. A. Detail of wide-angle sediment reflections and $P$-wave and $S$-wave refractions from the uppermost crust, for S/B 3 C record section at $4 \mathrm{~km} / \mathrm{s}$ reducing velocity. Normal incidence reflection record from Profile 3 (Fig. 5) near S/B 3C is shown at left edge. B. Corresponding asymptotic ray synthetic seismogram using ridge velocity structure of Figure 11A. Two-way traveltimes to model reflectors (arrows) are given at normal incidence. SF is seafloor and $\mathrm{B}$ is basement reflector. 

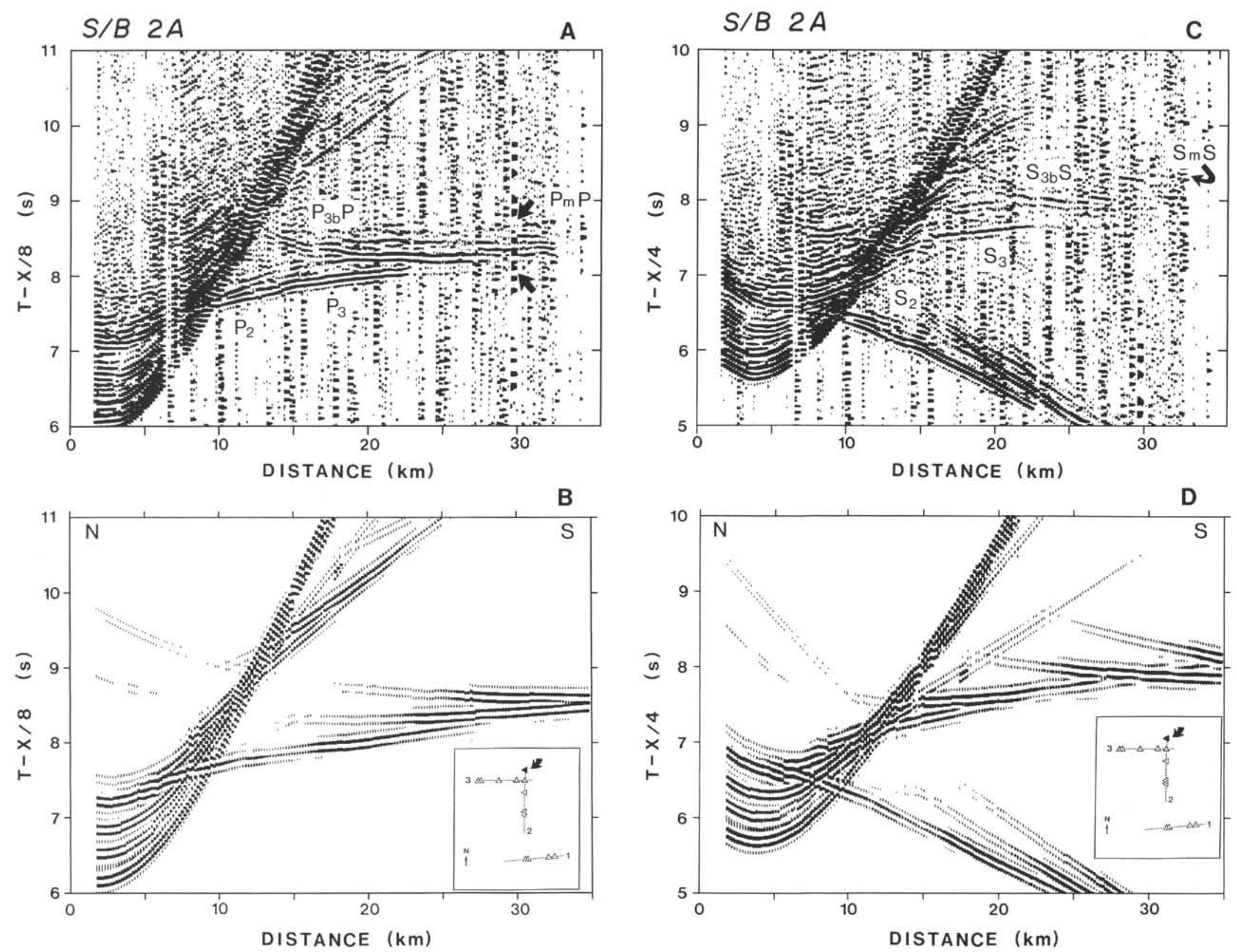

Figure 9. Record sections for S/B 2A (see insert for location) at reducing velocities of A. $8 \mathrm{~km} / \mathrm{s}$, and C. $4 \mathrm{~km} / \mathrm{s}$ compared to the corresponding asymptotic ray synthetic seismograms in (B) and (D) for the ridge structure of Figure 11A. Certain $P$-wave and $S$-wave refraction and wide-angle reflection phases are identified. Arrows define approximate limit for seismic wavetrain at $30 \mathrm{~km}$. 
$S / B$ IB

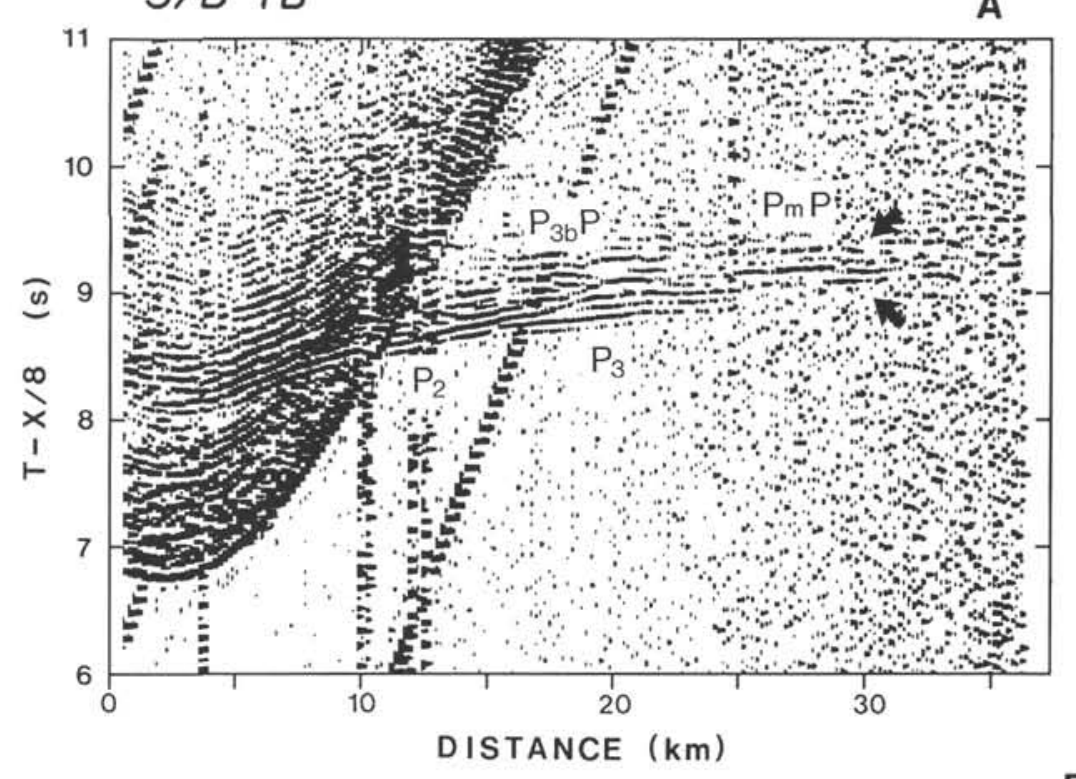

B

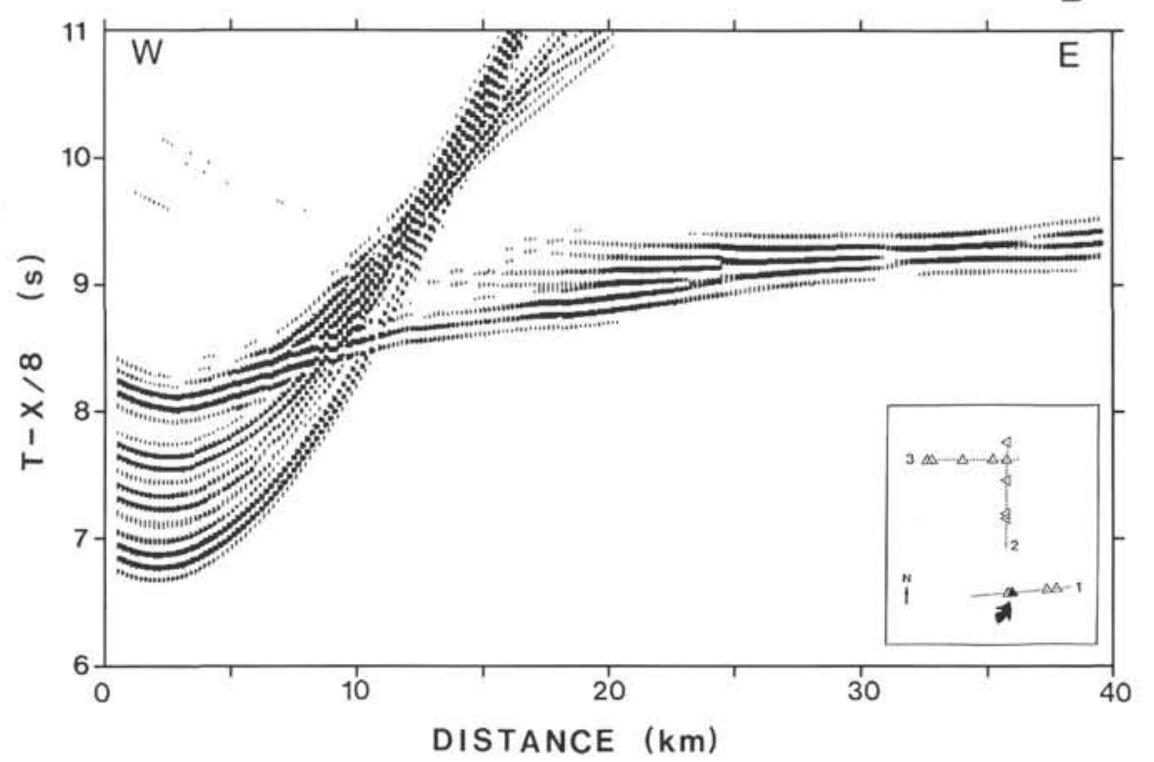

$S / B \quad B$

C

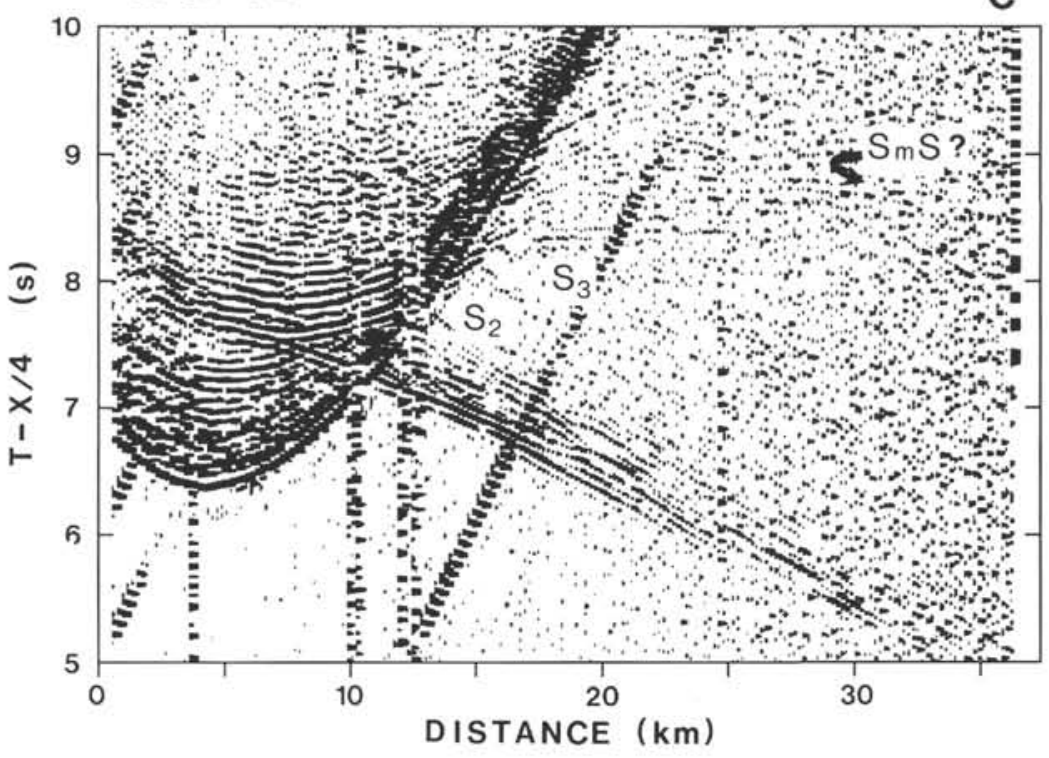

D

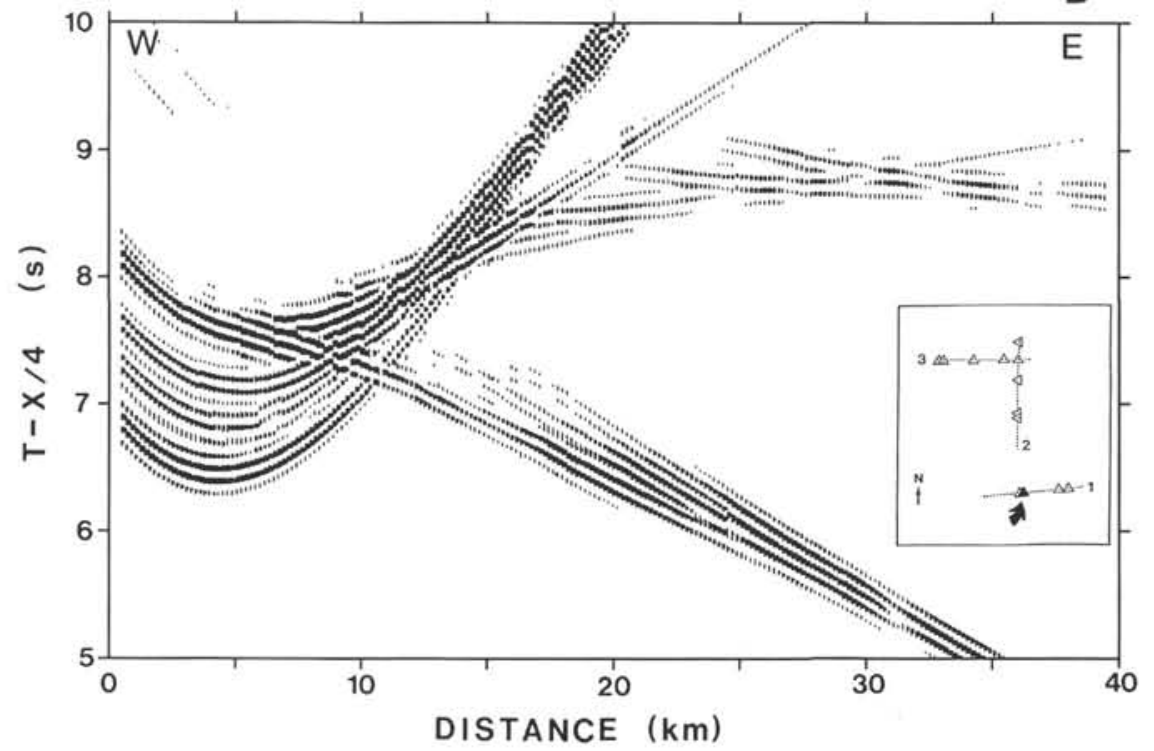

Figure 10. Record sections for S/B 1B (see insert for location) at reducing velocities of A. $8 \mathrm{~km} / \mathrm{s}$, and C. $4 \mathrm{~km} / \mathrm{s}$ compared to the corresponding asymptotic ray synthetic seismograms in (B) and (D) for the trough structure of Figure 11B. Certain $P$-wave and $S$-wave refraction and wide-angle reflection phases are identified. Arrows define approximate limit for seismic wave-train at $30 \mathrm{~km}$, which is narrower than for S/B $2 \mathrm{~A}$ (Fig. 9). 
angle reflections from the layer $3 a / 3 b$ boundary on S/B $2 A$ (Fig. 9a). which begin at $13 \mathrm{~km}$, are not predicted by our model, nor are they observed on the other ridge profiles. The rather weak $P_{\mathrm{m}} P$ wide-angle reflections from the Moho suggest that our models could generally be improved most by including a transition zone at the base of layer $3 \mathrm{~b}$. Finally, we note that our mantle $P$-wave velocity of $8.1 \mathrm{~km} / \mathrm{s}$ is assumed and not constrained by direct observation of $P_{\mathrm{n}}$. However, none of these limitations significantly compromises our major finding, independently confirmed by both $P$-wave and $S$-wave analysis, that the structure of the ridge crust is thicker than that of the trough.

\section{DISCUSSION}

A comparison of our final velocity-depth models to the earlier plane-layer solutions is given in Figure 11. The similarity of the two trough models, one from the north and another from the south of the elevated topographic block (see Figure 2 for locations), suggests that this structure is representative of undeformed oceanic crust in this region. The two ridge models from the same elevated basement block are at first glance different, as ours implies thickening under the ridge, and the plane-layer solutions suggest a uniform or slightly reduced thickness. However, if we equate the plane-layer velocities of $7.2-7.8 \mathrm{~km} / \mathrm{s}$ with layer $3 \mathrm{~b}$ rather than the mantle, these two models become much more consistent.

Our seismic models exhibit a $1.7 \mathrm{~km}$ or $22 \%$ thickening of the crust under the ridge relative to that under the trough. This increase is created entirely by the thickening of layers 3a (by $26 \%$ ) and 3 b (by $40 \%-46 \%$ ). Such thickening is remarkably consistent with predictions based on the hydrodynamic model for lithospheric deformation of Zuber (1987) as shown in Figure 12. Her preferred model with $S=1$ exhibits a $30 \%$ thickening associated with the elevated topography, which is uniformly distributed throughout the strong layer (i.e., crust and mantle). In contrast, the buckling model of McAdoo and Sandwell (1985) allows no thickening. The agreement between crustal thickness variations from our results and those of the preferred hydrodynamic model offers strong support for it.

This conclusion appears to contradict previous analysis of the gravity-bathymetry relationship (Weissel and Haxby, 1982), which required a crust of uniform thickness. In Table 2 , however, we show from simple calculation of mass columns, for a range of possible density values related to our seismic velocity models (Barton, 1986), expected free-air anomalies between trough and ridge of $40 \pm 10 \mathrm{mGal}$ from our synthetic model vs. approximately $70 \mathrm{mGal}$ for the plane-layer solutions. Using values from Table 2, a constant crustal thickness between ridge and trough results in a predicted gravity anomaly of 57 to $66 \mathrm{mGal}$ for both sediment models.

Free-air gravity anomalies, calculated from Seasat profiles (Haxby, 1987) and shown in Fig. 13, range from -20 to -30 $\mathrm{mGal}$ along the eastern half of the ridge profile 3 , to -50 to $-55 \mathrm{mGal}$ along the trough profile 1 . The change in free-air anomaly from trough to ridge is thus 25 to $35 \mathrm{mGal}$, agreeing much more closely with predictions from our synthetic seismic model with crustal thickening than with either our firstarrival model with slight thinning or one with constant crustal thickness. As sediment densities measured at Sites 717 and 718 (Cochran, Stow et al., 1989) conform most closely to the $\rho_{\max }$ predictions for $V_{p}$ between 1.6 and $2.0 \mathrm{~km} / \mathrm{s}$, we have used these preferentially in all of the total-mass column calculations. However, the choice of alternate densities would not change our result by more than several $\mathrm{mGal}$. The use of our initial sediment velocity model (Table 1.B) would tend to reduce our expected free-air anomaly by approximately 10
$\mathrm{mGal}$, and place the expected gravity anomaly from the seismic model with crustal thickening even closer to observation. Using mixtures of maximal and minimal densities in various layers could alter these results. However, these simple calculations do show that our preferred seismic model with increasing thickness beneath the ridge is consistent with the gravity field.

Assuming that one accepts the existence of the crustal thickness variations associated with the ridge and trough structures, there remains the question of whether they were created at the time of the deformation (as implied in the hydrodynamic model), or whether they already had been formed by seafloor spreading at the time of crustal accretion. To answer this question, we need to compare our observed thickness variations with those found elsewhere in "standard" oceanic crust, unaffected by intraplate lithospheric deformation.

This task is complicated by the scarcity of wide-angle seismic data with comparable resolution from such regions. Most refraction data with high-density sampling (e.g., twoship multichannel expanding spread or equivalent air-gun shots to OBS receivers) have been taken near ridge crests, fracture zones, or continental margins. Existing data show much less variation in structure along flow lines of seafloor spreading than across them over scales of 100-200 km (e.g. Purdy, 1983; NAT Study Group, 1985). Because the crustal variations we document occur subparallel to the magnetic lineations, they exist along a flow line and therefore should have a relatively constant seismic structure. The similarity of velocity-depth structures in the troughs on either side of the basement ridge also supports this conclusion.

However, in other respects the variations in crustal structure between ridge and trough look very similar to those observed across flow lines. Old crust as thick as $7-8 \mathrm{~km}$ has been observed in the Atlantic and is often associated with high, layer 3b-type velocities throughout its lower section (Purdy, 1983; NAT Study Group, 1985). This crust can thin by several kilometers across flow lines over distances of 100-200 $\mathrm{km}$, and this thinning occurs preferentially by the reduction of the plutonic section in layer 3 and not layer 2. This is remarkably similar to the seismic refraction observations of this study, and suggests an origin by variations in accretionary processes. The only unusual aspect of our seismic velocity structures is the presence of a discrete layer $3 \mathrm{~b}$, with abrupt transition above into layer $3 \mathrm{a}$ and below into the mantle. This is rarely observed in oceanic crust, which generally has smooth gradations in velocity throughout layer 3 (e.g. Purdy, 1983). It is more similar to crust thickened by hot-spot activity that often shows a discrete layer 3b (e.g., Sinha et al., 1981), although its boundaries are still marked by gradients.

\section{CONCLUSIONS AND SPECULATIONS}

In this paper we have presented results from the analysis of three refraction profiles in the central Indian Ocean along and across a ridge-trough system typical of those thought to be produced by intraplate deformation. These show a fairly standard oceanic crustal structure for the trough, consisting of a 2.6 - to $2.7-\mathrm{km}$-thick layer $2\left(V_{p}\right.$ ranging from 4.6 to $6.6 \mathrm{~km} / \mathrm{s}$ and $V_{s}$ from 2.6 to $3.5 \mathrm{~km} / \mathrm{s}$ ) underlain by a $2.3-\mathrm{km}$-thick layer $3 \mathrm{a}\left(V_{p}=6.7 \mathrm{~km} / \mathrm{s}\right.$ and $\left.V_{s}=3.9 \mathrm{~km} / \mathrm{s}\right)$ and $2.0-\mathrm{km}$-thick layer $3 \mathrm{~b}\left(V_{p}=7.4 \mathrm{~km} / \mathrm{s}\right.$, and $\left.V_{s}=4.3 \mathrm{~km} / \mathrm{s}\right)$, for a total crustal thickness of $6.9-7.0 \mathrm{~km}$. The structure under the ridge has similar velocities but a total thickness of $8.6-8.9 \mathrm{~km}$. This increase is created entirely by the thickening of layers $3 a$ (by $26 \%$ ) and 3 b (by $40 \%-46 \%$ ), as constrained by observations of $P$ - and $S$-wave wide-angle reflections from the top and bottom of layers $3 \mathrm{a}$ and $3 \mathrm{~b}$. Additionally, we have shown, using 


\section{RIDGE PROFILES}

SYNTHETICS

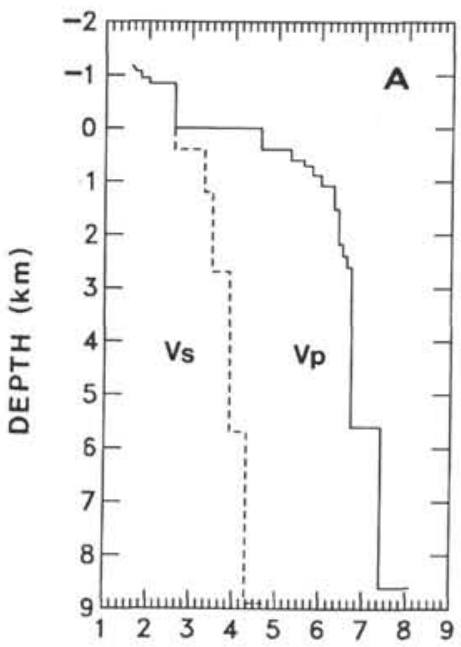

FIRST-ARRIVA LS

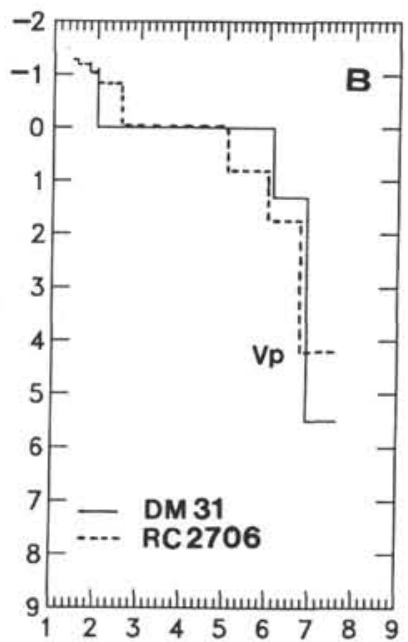

\section{TROUGH PROFILES}
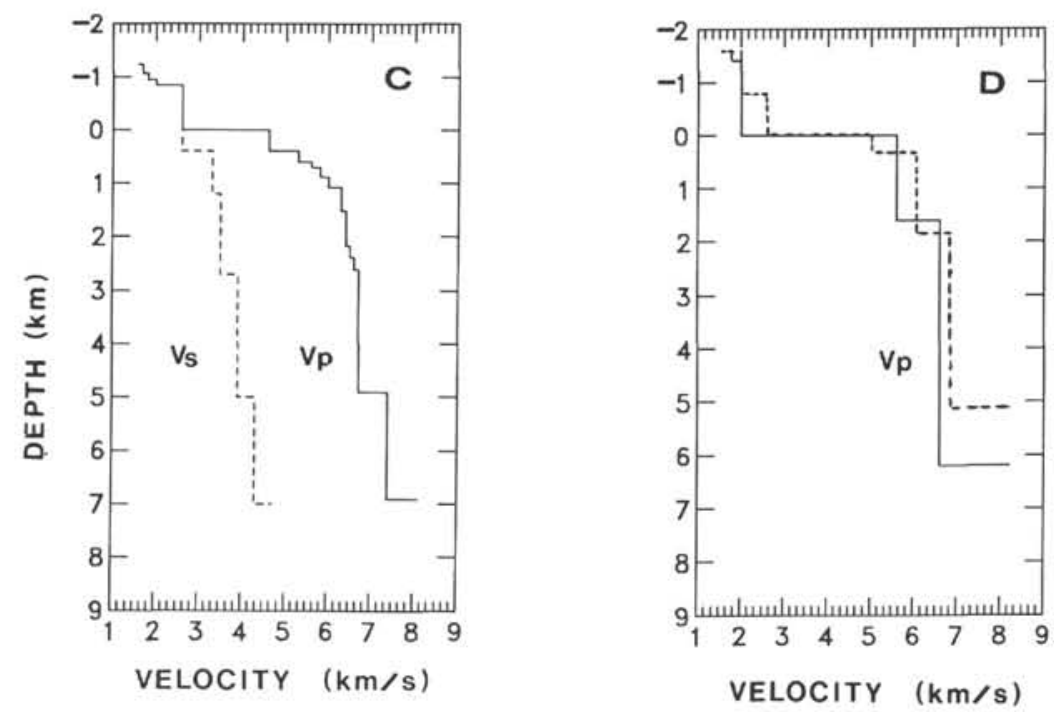

Figure 11. Velocity-depth models used to calculate synthetic seismograms in Figures 8 to 10 and $\mathrm{Al}$ to $\mathrm{A} 4$ for ridge $\mathrm{A}$ and trough $\mathrm{C}$ structures, compared to their corresponding plane-layer solutions $\mathbf{B}$ and $\mathbf{D}$ from Figure 6 .

sediment densities constrained by measurements from ODP Sites 717 and 718 together with a range of possible crustal densities suggested by the seismic velocities, that crustal thickening of this nature is consistent with the observed free-air gravity anomaly as derived from satellite measurements of the geoid.

Such crustal thickening is inconsistent with models of lithospheric deformation caused by the buckling of a strong but thin elastic core. Rather, it conforms more closely to models of hydrodynamic viscous flow which allow for folding accompanied by periodic layer thickening within a lithosphere of only moderate yield strength. However, the nature of the crustal variations, in which all of the thickening occurs within layer 3, suggests the possibility that they may not have been caused by the deformation, but were already formed by crustal accretion at the spreading center. If this is true, they may have produced vertical density contrasts over preferred deformational wavelengths (typically scales of $100-200 \mathrm{~km}$ ) that helped the deformation to grow and positioned the topographic highs in regions of thick crust. In this manner, variations in crustal accretionary processes may be linked to the random boundary disturbances in the hydrodynamic models. This supplemental process, in addition to previously suggested variations caused by fracture zones, may explain the rather blocky, three-dimensional detailed structure that exists within the overall regular pattern predicted by the simplified deformation models. Further observations of crustal variations over a number of other ridge-trough struc- 
$\lambda_{d} / h=13.7 \quad S=0.1$
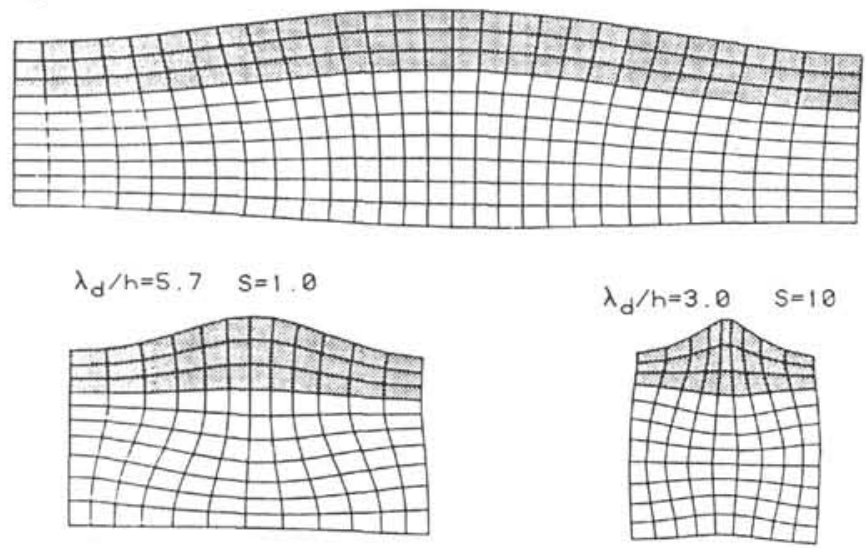

strong laver

Figure 12. Deformational styles predicted by the hydrodynamical flow model for a surface topography of $1 \mathrm{~km}$ (from Zuber, 1987). Preferred model is $\mathrm{S}=1$, for which the crust (roughly corresponding to the uppermost grid cell) is approximately $30 \%$ thicker under the high than under the trough. Note that in this representation, uniform horizontal shortening has been removed so that regions of apparent extension are actually areas of minimum compression. tures, as well as theoretical models including pre-existing structural variations, are necessary to confirm and quantify this suggestion.

\section{ACKNOWLEDGMENTS}

This experiment was planned and conducted in collaboration with D. W. Forsyth (Brown University) and J. K. Weissel (LDGO) who provided us with the shipboard data and helpful advice. C. Beaumont, M. Salisbury, M. J. Keen, and D. Kelly contributed constructive criticisms; J. Osler helped review the text. N. Hamilton provided technical expertise in the acquisition and analysis of the OBS data. Thanks also to the officers and crew of the Robert Conrad. This work was funded by grants from the U.S. National Science Foundation (OCE8511894) and the Natural Sciences and Engineering Research Council of Canada (OGP0008459). G.T.L. was supported by a Dalhousie University Fellowship and by $\mathrm{H}$. Macpherson of OceanRoutes Canada.

Table 2. Density columns from seismic structures.

\begin{tabular}{|c|c|c|c|c|c|c|c|c|c|}
\hline Layer & $\begin{array}{c}V_{p} \\
(\mathrm{~km} / \mathrm{s})\end{array}$ & $\begin{array}{c}\rho_{\mathrm{av}} \\
\left(\mathrm{Mg} / \mathrm{m}^{3}\right)\end{array}$ & $\begin{array}{r}\rho_{\min } \\
\left(\mathrm{Mg} / \mathrm{m}^{3}\right)\end{array}$ & $\begin{array}{r}\rho_{\max } \\
\left(\mathrm{Mg} / \mathrm{m}^{3}\right)\end{array}$ & $\underset{(\mathrm{km})}{\mathrm{H}_{\mathrm{R}}}$ & $\begin{array}{l}\mathrm{H}_{\mathrm{T}} \\
(\mathrm{km})\end{array}$ & $\begin{array}{c}\text { DSUMA } \\
\left(\mathrm{Mg} \times 10^{3}\right)\end{array}$ & $\begin{array}{l}\text { DSUMN } \\
\left(\mathrm{Mg} \times 10^{3}\right)\end{array}$ & $\begin{array}{l}\text { DSUMX } \\
\left(\mathrm{Mg} \times 10^{3}\right)\end{array}$ \\
\hline \multicolumn{10}{|c|}{ (A) SYNTHETIC MODEL } \\
\hline Water & 1.5 & 1.03 & & & 4.65 & 5.15 & -0.515 & & \\
\hline Sediment & $\begin{array}{l}1.6 \\
1.7 \\
1.8 \\
2.0 \\
2.6\end{array}$ & $\begin{array}{l}1.66 \\
1.73 \\
1.80 \\
1.92 \\
2.11\end{array}$ & $\begin{array}{l}1.33 \\
1.44 \\
1.54 \\
1.68 \\
1.96\end{array}$ & $\begin{array}{l}1.95 \\
2.05 \\
2.13 \\
2.20 \\
2.33\end{array}$ & $\begin{array}{l}0.10 \\
0.12 \\
0.11 \\
0.32 \\
0.51 \\
1.16\end{array}$ & $\begin{array}{l}0.17 \\
0.12 \\
0.11 \\
0.32 \\
0.65 \\
1.37\end{array}$ & $\begin{array}{l}-0.116 \\
0 \\
0 \\
0 \\
-0.295 \\
-0.412\end{array}$ & $\begin{array}{c}-0.093 \\
0 \\
0 \\
0 \\
-0.274 \\
-0.368\end{array}$ & $\begin{array}{l}-0.137 \\
0 \\
0 \\
0 \\
-0.326 \\
-0.463\end{array}$ \\
\hline $\begin{array}{l}\text { Layer } 3 \\
\text { SUM }\end{array}$ & $\begin{array}{l}6.7 \\
7.4\end{array}$ & $\begin{array}{l}2.95 \\
3.16\end{array}$ & $\begin{array}{l}2.66 \\
3.02\end{array}$ & $\begin{array}{l}3.11 \\
3.35\end{array}$ & $\begin{array}{l}3.00 \\
3.00 \\
6.00\end{array}$ & $\begin{array}{l}2.30 \\
2.00 \\
4.30\end{array}$ & $\begin{array}{l}2.065 \\
3.160 \\
5.225\end{array}$ & $\begin{array}{l}1.862 \\
3.020 \\
4.882\end{array}$ & $\begin{array}{l}2.177 \\
3.350 \\
5.527\end{array}$ \\
\hline Mantle & 8.1 & 3.38 & 3.14 & 3.40 & 0.00 & 0.99 & -3.346 & -3.109 & -3.366 \\
\hline $\begin{array}{l}\text { Crust } \\
\text { SUM } \\
\text { FAA (mGal) }\end{array}$ & & & & & & & $\begin{array}{l}0.901 \\
38\end{array}$ & $3^{0.796}$ & ${ }_{50}^{1.183}$ \\
\hline \multicolumn{10}{|c|}{ (B) PLANE-LAYER MODEL } \\
\hline Water & 1.5 & 1.03 & & & 4.65 & 5.15 & -0.515 & & \\
\hline Sediment & $\begin{array}{c}1.6 \\
1.8-2.0 \\
2.6\end{array}$ & $\begin{array}{l}1.66 \\
1.86 \\
2.11\end{array}$ & $\begin{array}{l}1.33 \\
1.62 \\
1.96\end{array}$ & $\begin{array}{l}1.95 \\
2.18 \\
2.33\end{array}$ & $\begin{array}{l}0.06 \\
0.37 \\
0.82 \\
1.25\end{array}$ & $\begin{array}{l}0.04 \\
0.75 \\
0.79 \\
1.58\end{array}$ & $\begin{array}{r}0.033 \\
-0.707 \\
0.063 \\
-0.610\end{array}$ & $\begin{array}{r}0.027 \\
-0.616 \\
0.059 \\
-0.530\end{array}$ & $\begin{array}{r}0.039 \\
-0.828 \\
0.070 \\
-0.720\end{array}$ \\
\hline Layer 2 & $\begin{array}{l}5.0 \\
6.0\end{array}$ & $\begin{array}{l}2.57 \\
2.77\end{array}$ & $\begin{array}{l}2.36 \\
2.44\end{array}$ & $\begin{array}{l}2.74 \\
2.88\end{array}$ & $\begin{array}{l}0.82 \\
0.91 \\
1.73\end{array}$ & $\begin{array}{l}0.33 \\
1.52 \\
1.85\end{array}$ & $\begin{array}{r}1.259 \\
-1.690 \\
-0.430\end{array}$ & $\begin{array}{r}1.156 \\
-1.488 \\
-0.332\end{array}$ & $\begin{array}{r}1.343 \\
-1.757 \\
-0.414\end{array}$ \\
\hline Layer 3 & 6.8 & 2.98 & 2.69 & 3.16 & 2.45 & 3.25 & -2.384 & -2.152 & -2.528 \\
\hline Mantle & 7.7 & 3.25 & 3.12 & 3.40 & 1.75 & 0.00 & 5.688 & 5.460 & 5.950 \\
\hline $\begin{array}{l}\text { Crust } \\
\text { SUM } \\
\text { FAA (mGal) }\end{array}$ & & & & & & & ${ }_{69}^{1.639}$ & $7^{1.742}$ & ${ }_{74}^{1.773}$ \\
\hline
\end{tabular}

Explanations:

Average $\left(\rho_{\mathrm{av}}\right)$, minimum $\left(\rho_{\min }\right)$ and maximum $\left(\rho_{\max }\right)$ density values associated with velocities Vp are taken from Barton [1986].HR and HT are layer thicknesses (in $\mathrm{km}$ ) for ridge and trough seismic structures from Table 1 (synthetic model) and averages from Fig. 6 (plane-layer model).

$\begin{aligned} & \text { DSUMA } \\ & \text { DSUMN } \\ & \text { DSUMX }\end{aligned}|=| \begin{aligned} & \rho_{\mathrm{av}} \\ & \rho_{\min } \\ & \rho_{\max }\end{aligned} \mid *\left(\mathrm{H}_{\mathrm{R}}-\mathrm{H}_{\mathrm{T}}\right)$

SUMS are separate summations of column values $\left(\mathrm{H}_{\mathrm{R}}, \mathrm{H}_{\mathrm{T}}\right.$, DSUMA, DSUMN and DSUMX) for sediment, layer 2, layer 3 and mantle.

SUMs for crust include all individual layer DSUMs of appropriate column, except DSUMX is always used for sediment layer.

FAA $=$ Free-Air Gravity Anomaly $(\mathrm{mGal})=($ Crustal DSUM $) * 41.9$ 


\section{REFERENCES}

Barton, P. J., 1986. The relationship between seismic velocity and density in the continental crust-a useful constraint? Geophys. J. R. Astron. Soc., 87:195-208.

Bergman, E. A., and Solomon, S. C., 1980. Oceanic intraplate earthquakes: implications for local and regional intraplate stress. $J$. Geophys. Res., 85:5389-5410.

1985. Earthquake source mechanisms from body waveform inversion and intraplate tectonics in the northern Indian Ocean. Phys. Earth Planet. Inter., 40:1-23.

Bodine, J. H., Steckler, M. S., and Watts, A. B., 1981. Observations of flexure and the rheology of the oceanic lithosphere. J. Geophys. Res., 86:3695-3707.

Canadian Hydrographic Service, 1982. General Bathymetric Chart of the Oceans (GEBCO) (5th ed.), Ottawa, Canada.

Cerveny, V., Molotkow, I. A., Psencik, I., 1977. Ray Method in Seismology: Praha (Karlova Univ.).

Cerveny, V., and Ravindra, R., 1971. Theory of Seismic Head Waves: Toronto (Univ. Toronto Press).

Cloetingh, S., and Wortel, R., 1986. Stress in the Indo-Australian Plate. Tectonophysics, 132:49-67.

Cochran, J. R., Stow, D.A.V., et al., 1989. Proc. ODP, Init. Repts., 116: College Station, TX (Ocean Drilling Program).

Eittreim, S. L., and Ewing, J., 1972. Midplate tectonics in the Indian Ocean. J. Geophys. Res., 77:6413-6421.

Geller, C. A., Weissel, J. K., and Anderson, R. N., 1983. Heat transfer and intraplate deformation in the central Indian Ocean. $J$. Geophys. Res., 88:1018-1032.

Goetze, C., and Evans, B., 1979. Stress and temperature in the bending lithosphere as constrained by experimental rock mechanics. Geophys. J. R. Astron. Soc., 59:463-478.

Haxby, W. F., 1987. Gravity Field of the World's Oceans: Boulder (National Geophysical Data Center).

Heffler, D. E., and Barrett, D. L., 1979. OBS development at Bedford Institute of Oceanography. Mar. Geophys. Res., 4:227-245.

Kirby, S. H., 1983. Rheology of the lithosphere. Rev. Geophys., $21: 1458-1487$.

Leger, G. T., 1989. Was the Oceanic crust in the central Indian Basin deformed by lithospheric boudinage? Evidence from seismic refraction [M.S. thesis]. Dalhousie University, Halifax.

Lewis, B. R., and McClain, J., 1977. Converted shear waves as seen by ocean bottom seismometers and surface buoys. Bull. Seis. Soc. Am., 67:1291-1302.

McAdoo, D. C., and Sandwell, D. T., 1985. Folding of oceanic lithosphere. J. Geophys. Res., 90:8563-8569.

NAT Study Group, 1985. North Atlantic Transect: a wide-aperature, two-ship multichannel seismic investigation of the oceanic crust. J. Geophys. Res., 90:10321-10341.

Neprochnov, Y. P., Levchenko, O. V., Merklin, L. R., and Sedov, V. V., 1988. The structure and tectonics of the intraplate deformation area in the Indian Ocean. Tectonophysics, 156:89-106.

Purdy, G. M., 1982. The correction for the travel time effects of seafloor topography in the interpretation of marine seismic data. $J$. Geophys. Res., 87:8389-8396.
1983. The seismic structure of $\mathrm{i}+0 \mathrm{Myr}$ old crust in the western central Atlantic Ocean. Geophys. J. R. Astron. Soc., 72:115-137.

Richardson, R. M., 1987. Modeling the tectonics of the Indo-Australian Plate. EOS, Trans. Am. Geophys. Union, 68:1466. (Abstract)

Sclater, J. G., and Fisher, R. L., 1974. The evolution of the east central Indian Ocean with emphasis on the tectonic setting of the Ninetyeast Ridge. Geol. Soc. Am. Bull., 85:683-702.

Shipboard Scientific Party, 1989a. Site 718: Bengal Fan. In Cochran, J. R., Stow, D.A.V., et al., Proc. ODP, Init. Repts., 116: College Station, TX (Ocean Drilling Program), 91-154.

1989b. ODP Leg 116 Site Survey. In Cochran, J. R., Stow, D.A.V., et al., Proc. ODP, Init. Repts., 116: College Station, TX (Ocean Drilling Program), 197-212.

Sinha, M. C., Louden, K. E., and Parsons, B., 1981. The crustal structure of the Madagascar Ridge. Geophys. J. R. Astron. Soc., 66:351-377.

Spudich, P., and Orcutt, J., 1980. Petrology and porosity of an oceanic crustal site: results from wave form modeling of seismic refraction data. J. Geophys. Res., 85:1409-1433.

Stein, C. A., Cloetingh, S., and Wortel, R., 1989. SEASAT-derived gravity constraints on stress and deformation in the northeastern Indian Ocean. Geophys. Res. Lett., 16:823-826.

Stein, S., and Okal, E. A., 1978. Seismicity and tectonics of the Ninetyeast Ridge area: evidence for internal deformation of the Indian Plate. J. Geophys. Res., 83:2233-2245.

Sykes, L. R., 1970. Seismicity of the Indian Ocean and a possible nascent island arc between Ceylon and Australia. J. Geophys. Res., 75:5041-5055.

Weissel, J. K., Anderson, R. N., and Geller, C. A., 1980. Deformation of the Indo-Australian Plate. Nature, 287:284-291.

Weissel, J. K., and Haxby, W. F., 1982. Predicting seafloor topography from SEASAT altimeter data using isostatic models. EOS, Trans. Am. Geophys. Union, 63:907. (Abstract)

White, R. S., and Stephen, R. A., 1980. Compressional to shear wave conversion in oceanic crust. Geophys. J. R. Astron. Soc., 63:547565 .

Wiens, D. A., DeMets, C., Gordon, R. G., Stein, S., Argus, D., Engeln, F. J., Lundgren, P., Quible, D., Stein, C., Weinstein, S., and Woods, D. F., 1985. A diffuse plate boundary model for Indian Ocean tectonics. Geophys. Res. Lett., 12:429-432.

Wiens, D. A., and Stein, S., 1983. Age dependence of oceanic seismicity and implications for lithospheric evolution. J. Geophys. Res., 88:6455-6468.

Zuber, M. T., 1987. Compression of oceanic lithosphere: an analysis of intraplate deformation in the central Indian Ocean. J. Geophys. Res., 92:4817-4825.

Date of initial receipt: 4 August 1989

Date of acceptance: 15 February 1990

Ms 116B-156 


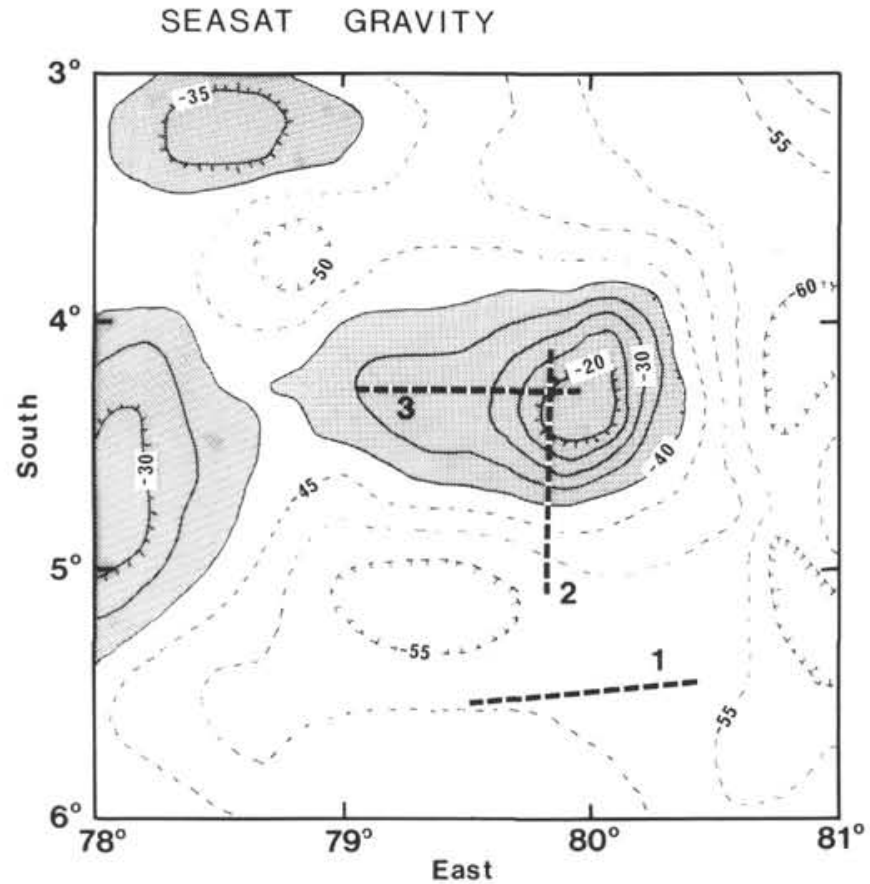

Figure 13. Geoid-derived free-air gravity anomalies (in $\mathrm{mGal}$ ) for the detailed study region of Fig. 2 (from Haxby, 1987). Contours every 5 $\mathrm{mGal}$ are broken for values $\leq-45 \mathrm{mGal}$ and solid for values $\geq-40$ $\mathrm{mGal}$. Regions $>-40 \mathrm{mGal}$ are shaded. Seismic profiles $1-3$ are located by broken lines. 
S/B $3 C$

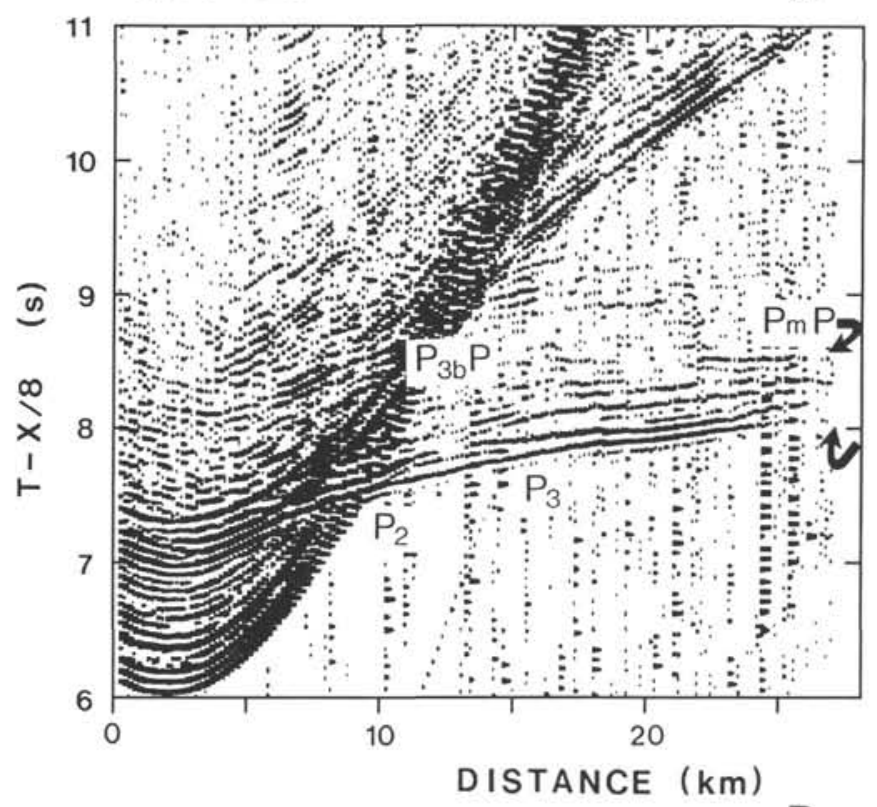

B

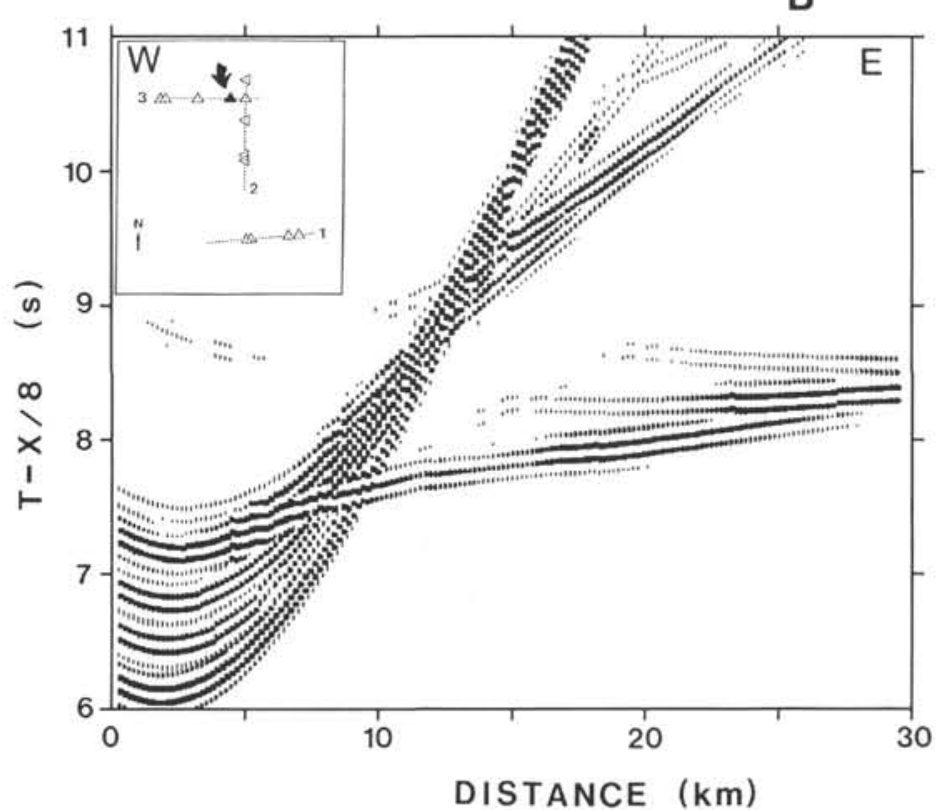

$S / B 3 C$

C
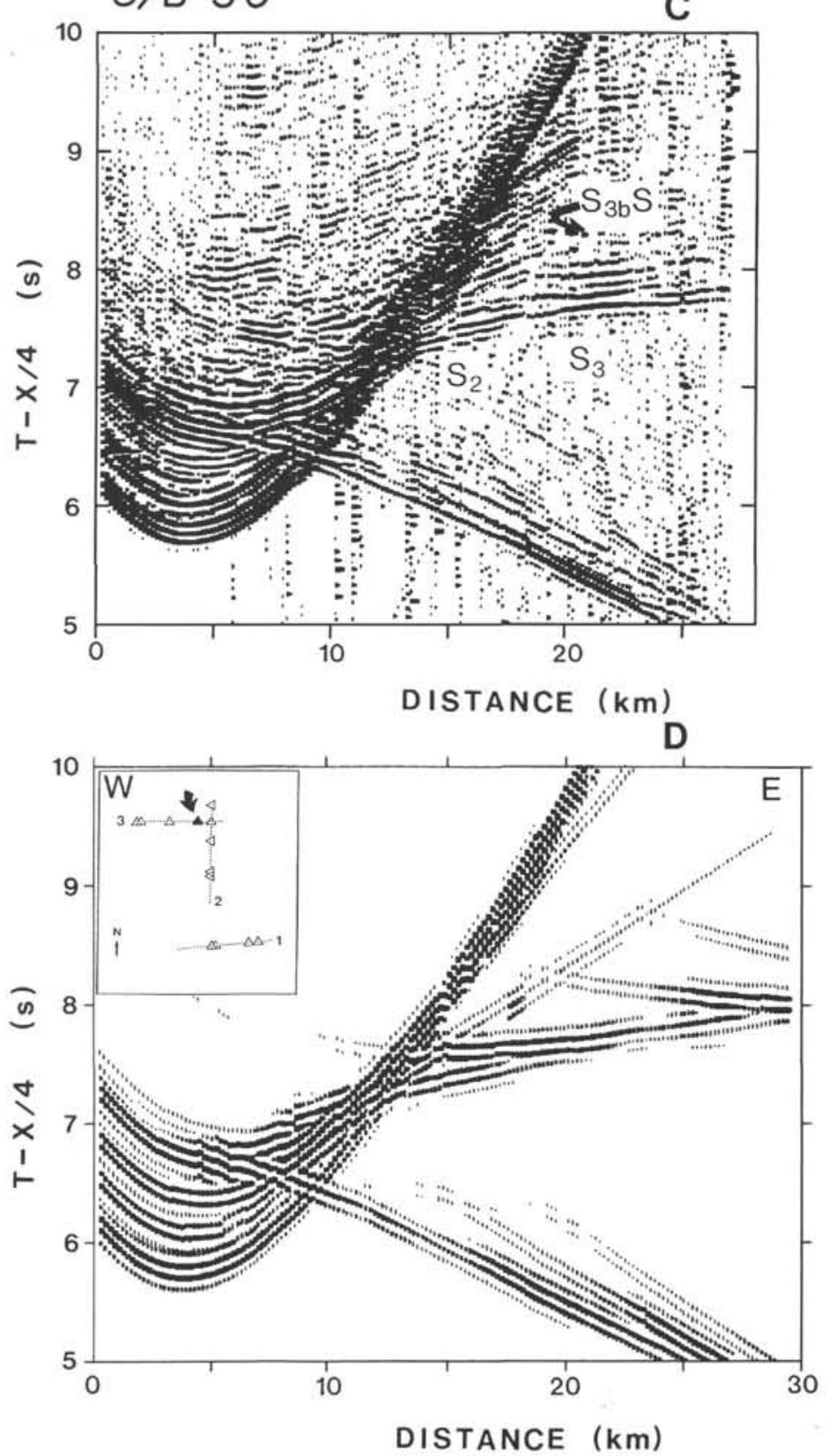

Figure A1. Record sections for S/B 3C (see insert for location) at reducing velocities of A. $8 \mathrm{~km} / \mathrm{s}$, and C. $4 \mathrm{~km} / \mathrm{s}$, compared to the corresponding asymptotic-ray synthetic seismograms in (B) and (D) for the ridge structure of Figure 11A. Certain $P$-wave and $S$-wave refraction and wide-angle reflection phases are identified. Arrows define approximate limit for seismic wavetrain at $27 \mathrm{~km}$. 
$S / B 2 C$

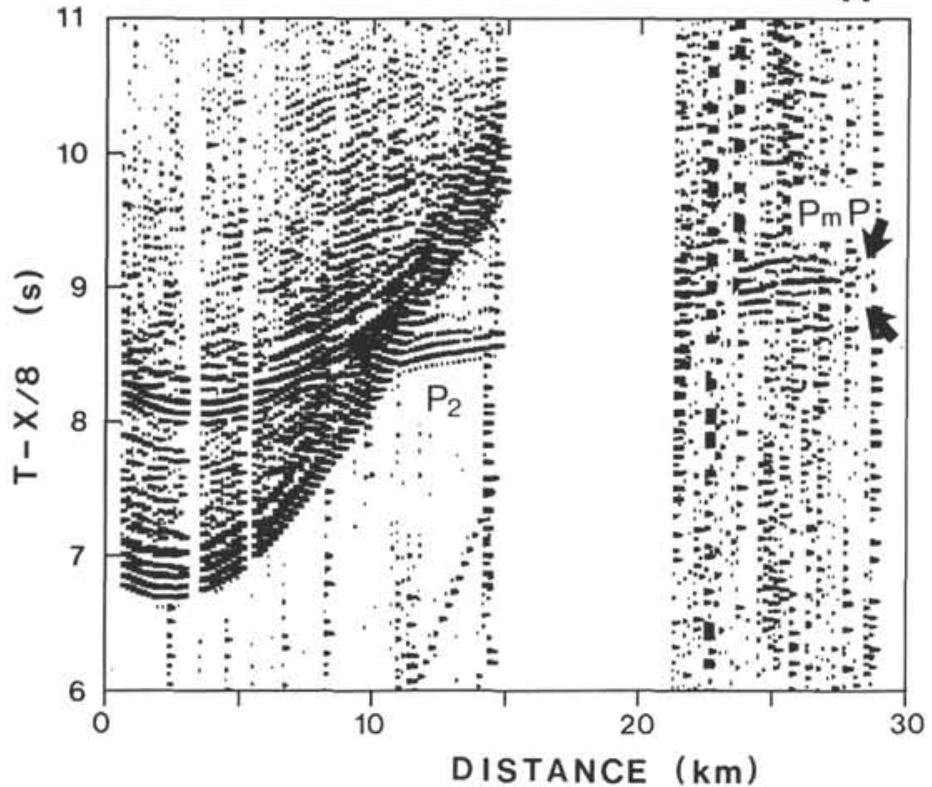

DISTANCE $(\mathrm{km})$

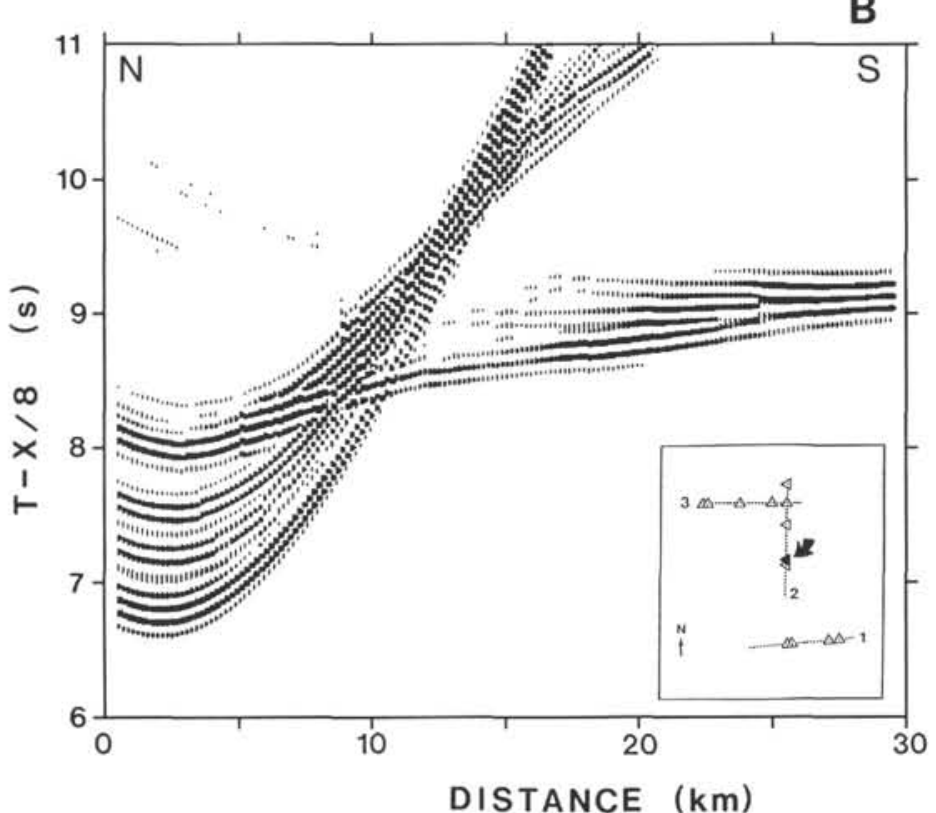

$S / B 2 C$
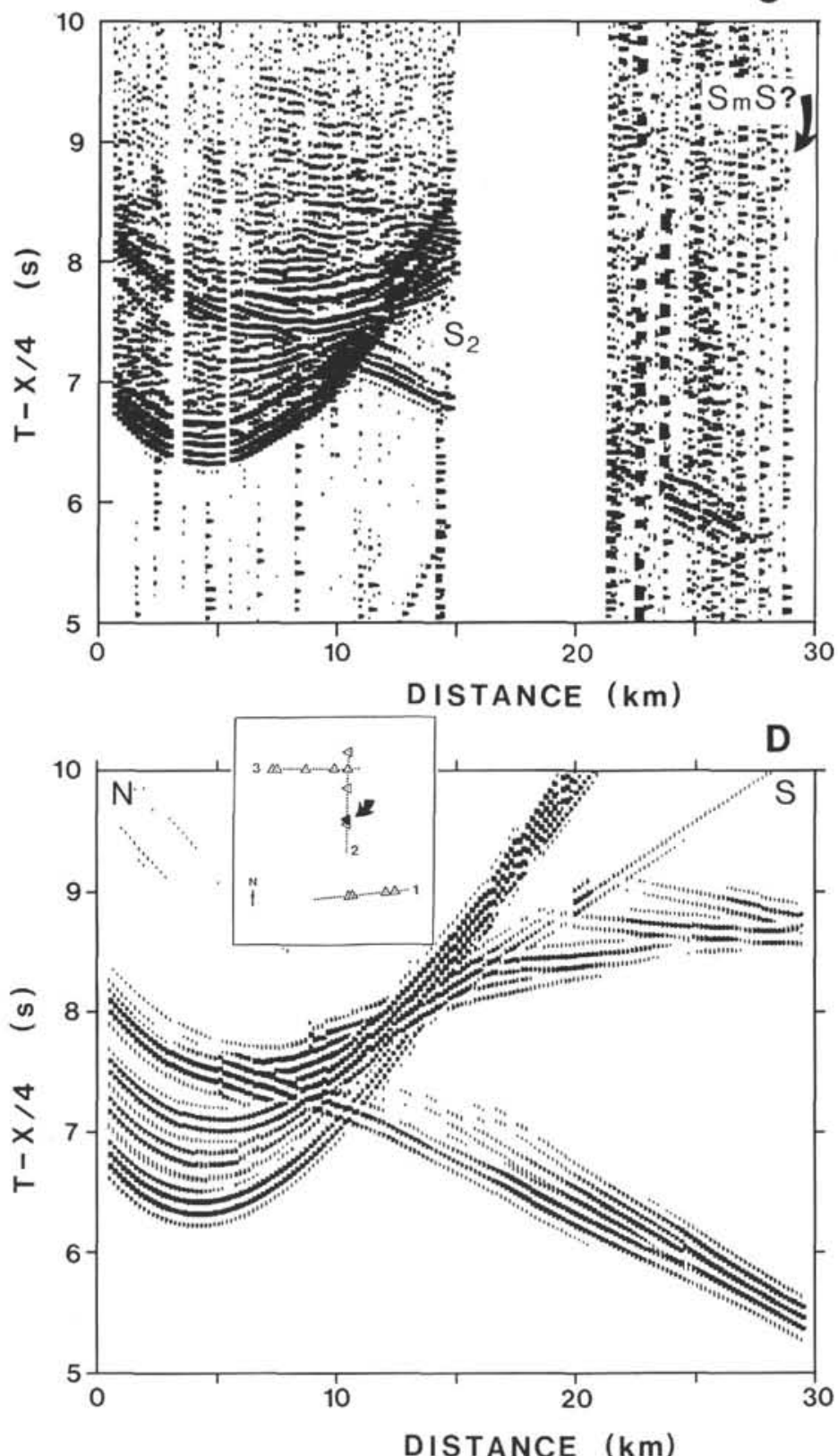

Figure A2. Record sections for S/B 2C (see insert for location) at reducing velocities of A. $8 \mathrm{~km} / \mathrm{s}$, and C. $4 \mathrm{~km} / \mathrm{s}$, compared to the corresponding asymptotic-ray synthetic seismograms in (B) and (D) for trough structure of Figure 11B. Gap in record between 14 and $21 \mathrm{~km}$ is caused by malfunction of on-board recording. Certain $P$-wave and $S$-wave refraction and wide-angle reflection phases are identified. Arrows define approximate limit for seismic wave-train at $27 \mathrm{~km}$, which is narrower than for S/B 3C (Fig. A1). 

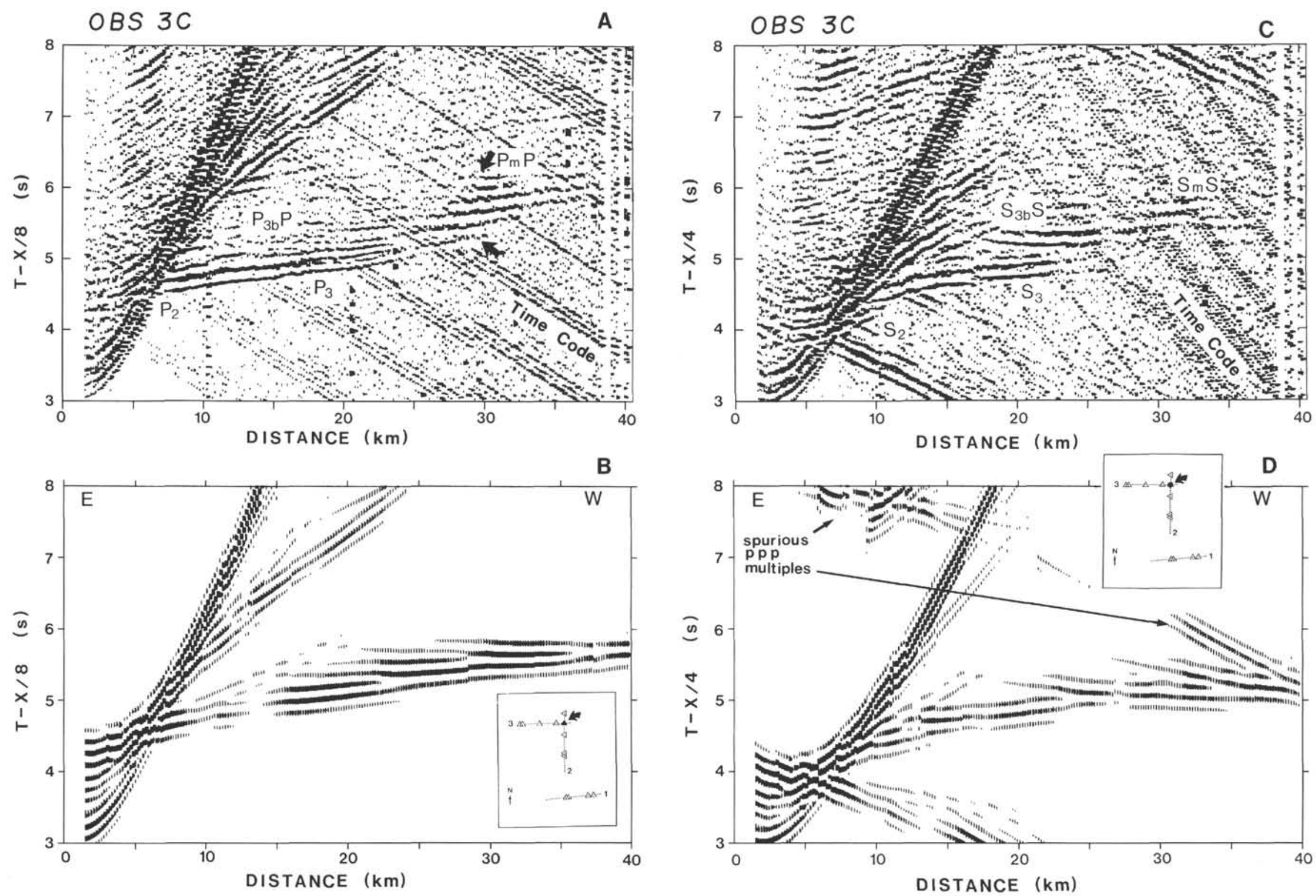

Figure A3. Record sections for OBS 3C (see insert for location) at reducing velocities of A. $8 \mathrm{~km} / \mathrm{s}$, and C. $4 \mathrm{~km} / \mathrm{s}$, compared to the corresponding asymptotic-ray synthetic seismograms in (B) and (D) for the ridge structure of Figure 11A. Spurious ppp multiples are an artifact of the model for treating the seafloor position of OBS. Certain $P$-wave and $S$-wave refraction and wide-angle reflection phases are identified. Arrows define approximate limit for seismic wavetrain at $30 \mathrm{~km}$. 

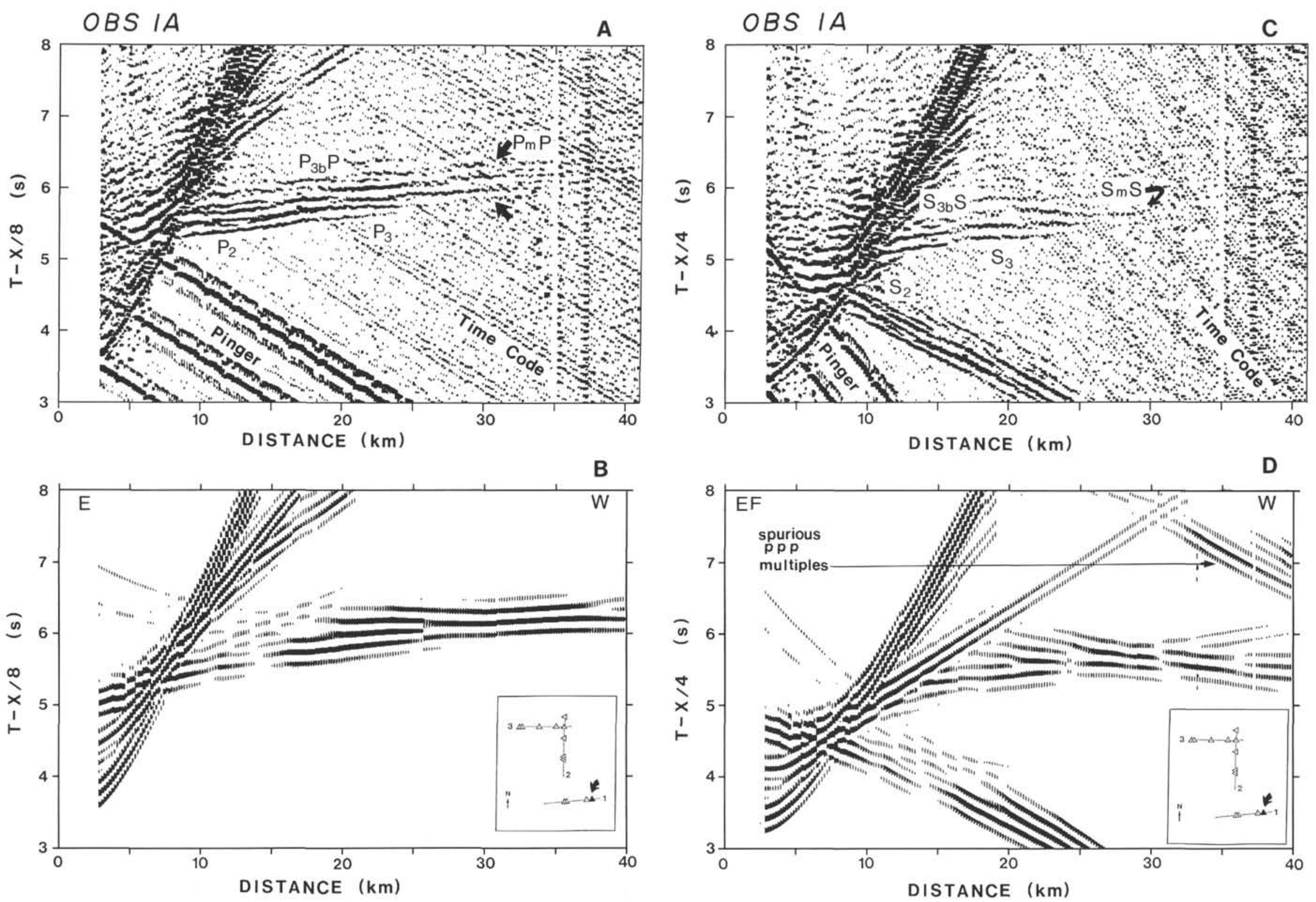

Figure A4. Record sections for OBS $1 \mathrm{~A}$ (see insert for location) at reducing velocities of A. $8 \mathrm{~km} / \mathrm{s}$, and C. $4 \mathrm{~km} / \mathrm{s}$, compared to the corresponding asymptotic-ray synthetic seismograms in (B) and (D) for the trough structure of Figure 11B. Spurious ppp multiples are an artifact of the model for treating the seafloor position of OBS. Certain $P$-wave and $S$-wave refraction and wide-angle reflection phases are identified. Arrows define approximate limit for seismic wavetrain at $30 \mathrm{~km}$, which is narrower than for OBS $3 \mathrm{C}$ (Fig. A3). 